\title{
An assessment of natural methane fluxes simulated by the CLASS-CTEM model
}

\author{
Vivek K. Arora ${ }^{1}$, Joe R. Melton ${ }^{2}$, and David Plummer ${ }^{1}$ \\ ${ }^{1}$ Canadian Centre for Climate Modelling and Analysis, Environment and Climate Change Canada, \\ University of Victoria, Victoria, BC, V8W 2Y2, Canada \\ ${ }^{2}$ Climate Research Division, Environment and Climate Change Canada, Victoria, BC, Canada
}

Correspondence: Vivek K. Arora (vivek.arora@canada.ca)

Received: 4 December 2017 - Discussion started: 19 December 2017

Revised: 29 May 2018 - Accepted: 18 June 2018 - Published: 1 August 2018

\begin{abstract}
Natural methane emissions from wetlands and fire, and soil uptake of methane, simulated using the Canadian Land Surface Scheme and Canadian Terrestrial Ecosystem (CLASS-CTEM) modelling framework, over the historical 1850-2008 period, are assessed by using a one-box model of atmospheric methane burden. This one-box model also requires anthropogenic emissions and the methane sink in the atmosphere to simulate the historical evolution of global methane burden. For this purpose, global anthropogenic methane emissions for the period 1850-2008 were reconstructed based on the harmonized representative concentration pathway (RCP) and Emission Database for Global Atmospheric Research (EDGAR) data sets. The methane sink in the atmosphere is represented using biascorrected methane lifetimes from the Canadian Middle Atmosphere Model (CMAM). The resulting evolution of atmospheric methane concentration over the historical period compares reasonably well with observation-based estimates (correlation $=0.99$, root mean square error $=35 \mathrm{ppb}$ ). The modelled natural emissions are also assessed using an inverse procedure where the methane lifetimes required to reproduce the observed year-to-year increase in atmospheric methane burden are calculated based upon the specified global anthropogenic and modelled natural emissions that we have used here. These calculated methane lifetimes over the historical period fall within the uncertainty range of observation-based estimates. The present-day (20002008) values of modelled methane emissions from wetlands (169 $\mathrm{Tg} \mathrm{CH}_{4} \mathrm{yr}^{-1}$ ) and fire $\left(27 \mathrm{Tg} \mathrm{CH}_{4} \mathrm{yr}^{-1}\right)$, methane uptake by soil ( $29 \mathrm{Tg} \mathrm{CH}_{4} \mathrm{yr}^{-1}$ ), and the budget terms associated with overall anthropogenic and natural emissions are
\end{abstract}

consistent with estimates reported in a recent global methane budget that is based on top-down approaches constrained by observed atmospheric methane burden. The modelled wetland emissions increase over the historical period in response to both increases in precipitation and in atmospheric $\mathrm{CO}_{2}$ concentration. This increase in wetland emissions over the historical period yields evolution of the atmospheric methane concentration that compares better with observation-based values than the case when wetland emissions are held constant over the historical period.

\section{Introduction}

Earth system models (ESMs) represent physical climate system processes and their interactions with biogeochemical processes focusing primarily on the carbon cycle in the context of carbon dioxide $\left(\mathrm{CO}_{2}\right)$. These models are able to project how the atmospheric concentration of carbon dioxide $\left(\left[\mathrm{CO}_{2}\right]\right)$ will change in response to changes in anthropogenic $\mathrm{CO}_{2}$ emissions or alternatively diagnose anthropogenic $\mathrm{CO}_{2}$ emissions required to achieve a specific $\mathrm{CO}_{2}$ concentration pathway (Jones et al., 2013). This capability is achieved by modelling $\left[\mathrm{CO}_{2}\right]$ as a prognostic variable, which itself requires modelling of the surface-atmosphere exchange of $\mathrm{CO}_{2}$ and hence the need for land and oceanic carbon cycle components in ESMs (Friedlingstein et al., 2006, 2014; Arora et al., 2013). While most ESMs include the capability of modelling $\left[\mathrm{CO}_{2}\right]$ as a prognostic variable, there are only a handful of ESMs that are beginning to treat the atmospheric concen- 
tration of methane, $\left(\left[\mathrm{CH}_{4}\right]\right)$, as a fully prognostic variable (Collins et al., 2011; Shindell et al., 2013).

The $\left[\mathrm{CH}_{4}\right]$ has increased from $700 \pm 25 \mathrm{ppb}$ in 1750 to $1795 \pm 18 \mathrm{ppb}$ in 2010 (Prather et al., 2012). The $\left[\mathrm{CO}_{2}\right]$ has increased globally from 278 (276-280) ppm in 1750 to 390.5 (390.3-390.7) ppm in 2011. The greater global warming potential of $\mathrm{CH}_{4}$ compared to $\mathrm{CO}_{2}$ (84 and 28 for 20-year and 100-year time scales, respectively), has made methane the second most radiatively important greenhouse gas (GHG) after $\mathrm{CO}_{2}$ (Myhre et al., 2013). The $\mathrm{CO}_{2}$ radiative forcing for the period 1750-2011 is $1.82 \mathrm{~W} \mathrm{~m}^{-2}$ (associated with $\sim 112 \mathrm{ppm}$ increase), while the radiative forcing for $\mathrm{CH}_{4}$ over the same period is $0.48 \mathrm{~W} \mathrm{~m}^{-2}$ (associated with $\sim 1081 \mathrm{ppb}=1.08 \mathrm{ppm}$ increase) (Myhre et al., 2013). As methane is a short-lived GHG with an atmospheric lifetime of around 9 years (compared to $\mathrm{CO}_{2}$ which has an atmospheric lifetime of around 100-200 years), mitigation of anthropogenic $\mathrm{CH}_{4}$ emissions can lead to a decrease in its atmospheric concentration within a timeframe of 1020 years. As a result, methane is considered a short-lived climate forcer (SLCF) and thus reduction in its anthropogenic emissions offers an attractive and potentially viable target for short-term climate change mitigation policies (Shindell et al., 2012). However, to be able to address climate benefits of reduction in anthropogenic $\mathrm{CH}_{4}$ emissions within the framework of comprehensive ESMs it is necessary to model $\left[\mathrm{CH}_{4}\right]$ as a prognostic variable in these models.

Treatment of $\left[\mathrm{CH}_{4}\right]$ as a fully prognostic variable in ESMs is hindered by at least two factors. First, the global $\mathrm{CH}_{4}$ budget is not as well understood as for $\mathrm{CO}_{2}$. Our lack of ability to close the present-day global $\mathrm{CH}_{4}$ budget is illustrated in Saunois et al. (2016) who present a recent synthesis of several studies and summarize the present-day global $\mathrm{CH}_{4}$ budget. Saunois et al. (2016) show a large discrepancy between total $\mathrm{CH}_{4}$ emissions, from both anthropogenic and natural sources, for the 2003-2012 period, as inferred from the top-down atmospheric inversion-based approaches (558 $\mathrm{Tg} \mathrm{CH}_{4} \mathrm{yr}^{-1}$ ) and those based on bottom-up modelling and other approaches $\left(736 \mathrm{Tg} \mathrm{CH}_{4} \mathrm{yr}^{-1}\right)$. The primary reason for this discrepancy is that there are multiple sources of both natural and anthropogenic $\mathrm{CH}_{4}$ emissions, so the bottom-up approaches that add up all the individual sources inevitably give larger total emissions than top-down approaches that are constrained by the atmospheric $\mathrm{CH}_{4}$ burden and its loss in the atmosphere. Second, unlike $\mathrm{CO}_{2}, \mathrm{CH}_{4}$ has a sink in the atmosphere, which requires representation of atmospheric chemistry in ESMs to properly account for the removal of $\mathrm{CH}_{4}$ and feedbacks of methane on chemistry. $\mathrm{CH}_{4}$ is destroyed in the troposphere and stratosphere due to its reaction with $\mathrm{OH}$ radicals and chlorine. This is typically very computationally expensive to represent. As an example, the model years per wall clock day simulated by the atmospheric component of the second generation Canadian Earth System Model (CanESM2; Arora et al., 2011) are reduced by a factor of around 6 when atmospheric chemistry is turned on.
Despite these two challenges there are ways forward to model $\left[\mathrm{CH}_{4}\right]$ as a fully prognostic variable and be able to use comprehensive ESMs to ask questions that the climate modelling community has asked so far in the context of $\mathrm{CO}_{2}$. For example, how would future $\left[\mathrm{CH}_{4}\right]$ change in response to changes in anthropogenic and natural $\mathrm{CH}_{4}$ emissions, or alternatively what should anthropogenic future $\mathrm{CH}_{4}$ emissions be to achieve a given $\mathrm{CH}_{4}$ concentration pathway, while anthropogenic $\mathrm{CO}_{2}$ emissions continue to increase? In terms of emissions, as the top-down estimates of $\mathrm{CH}_{4}$ emissions from natural and anthropogenic sources are better constrained than the bottom-up estimates they are likely to provide more robust estimates for evaluating ESMs and their $\mathrm{CH}_{4}$ related components. The expensive atmospheric chemistry modules can be replaced with simple first-order representations of chemical losses or, ignoring the spatial variations in $\mathrm{CH}_{4}$ concentration, the global average concentration of methane can be simulated with a box model using specified methane life times which are calculated a priori using full 3-D chemistry-climate models. Although, of course, using specified $\mathrm{CH}_{4}$ losses implies that feedbacks of methane on methane loss rates and interactions between atmospheric chemistry and climate can be neglected.

The CLASS-CTEM modelling framework serves as the land surface component in the family of Canadian ESMs (CanESMs) (Arora et al., 2009, 2011; Arora and Scinocca, 2016) developed by the Department of Environment and Climate Change, Government of Canada, and models the landatmosphere fluxes of water, energy, and $\mathrm{CO}_{2}$. It consists of the Canadian Land Surface Scheme (CLASS) and the Canadian Terrestrial Ecosystem Model (CTEM). In preparation for modelling $\left[\mathrm{CH}_{4}\right]$ as a prognostic variable in future versions of CanESMs we have included several $\mathrm{CH}_{4}$ related processes in the CLASS-CTEM modelling framework. These include representations of dynamic natural wetlands and their $\mathrm{CH}_{4}$ emissions, $\mathrm{CH}_{4}$ emissions from fires, and uptake of $\mathrm{CH}_{4}$ by soils. This paper evaluates the simulated spatial distribution of wetlands as well as the magnitude of $\mathrm{CH}_{4}$ emissions from wetlands and fires, and $\mathrm{CH}_{4}$ uptake by soils against their respective present-day observationbased estimates. We also evaluate the simulated time evolution of the global sums of these fluxes for the 1850-2008 period by using a one-box model of atmospheric $\mathrm{CH}_{4}$ burden. This one-box model requires anthropogenic $\mathrm{CH}_{4}$ emissions, emissions from other natural sources that are not modelled in the CLASS-CTEM framework, and a representation of atmospheric sinks. The anthropogenic $\mathrm{CH}_{4}$ emissions for the period 1850-2008 are obtained by harmonizing the RCP and EDGAR data sets, and natural emissions from sources that are not modelled are specified. Finally, the atmospheric sink of $\mathrm{CH}_{4}$ is based on bias-corrected global atmospheric lifetime of $\mathrm{CH}_{4}$ as computed by the Canadian Middle Atmosphere Model (CMAM). The one-box model of atmospheric $\mathrm{CH}_{4}$ burden is used to evaluate CLASS-CTEM simulated natural $\mathrm{CH}_{4}$ fluxes by comparing simulated evolution of 
global $\left[\mathrm{CH}_{4}\right]$ with their observation-based estimates as well as by comparing the $\mathrm{CH}_{4}$ lifetime required to reproduce the observed evolution of global $\left[\mathrm{CH}_{4}\right]$ over the historical period with their observation-based estimates.

The rest of this paper is organized as follows. A brief description of the CLASS-CTEM modelling framework is presented in Sect. 2 along with the details of methane related processes that are implemented, the data sets used and the experimental protocol. Results are presented in Sect. 3 and finally, discussion and conclusions are presented in Sect. 4.

\section{Model, data and experimental set up}

\subsection{The CLASS-CTEM model and its forcing and evaluation data sets}

\subsubsection{The CLASS-CTEM model}

The CLASS-CTEM modelling framework consists of the Canadian Land Surface Scheme (CLASS) and the Canadian Terrestrial Ecosystem Model (CTEM), which are coupled to each other and together simulate fluxes of energy, water, $\mathrm{CO}_{2}$, and now $\mathrm{CH}_{4}$ at the land-atmosphere boundary. Together, CLASS and CTEM form the land surface component in Canadian Earth System Models - CanESM1 (Arora et al., 2009), CanESM2 (Arora et al., 2011), and CanESM4.2 (Arora and Scinocca, 2016).

CLASS simulates atmosphere-land fluxes of energy and water and it prognostically calculates the liquid and frozen soil moisture contents, and soil temperature for its soil layers, the liquid and frozen moisture contents and temperature of the single vegetation canopy layer (if present), and the snow water equivalent and temperature of a single snow layer (if present). CLASS is described in detail in Verseghy (1991), Verseghy et al. (1993), and Verseghy (2000). In the version 3.6 of CLASS used here, the thicknesses of the three permeable soil layers are specified as $0.1,0.25$ and $3.75 \mathrm{~m}$, although the model can be configured to use any number of layers with specified thicknesses. The thicknesses of the permeable layers also depend on the depth to the bedrock which is specified on the basis of the global data set of Zobler (1986). For example, if the depth to bedrock is only $2 \mathrm{~m}$, then the thicknesses of the permeable soil layers are taken to be $0.1,0.25$ and $1.65 \mathrm{~m}$. The energy and water balance calculations are performed for four plant functional types (PFTs) (needleleaf trees, broadleaf trees, crops and grasses). CLASS operates at a sub-daily time step and a time step of $30 \mathrm{~min}$ is used here.

CTEM simulates the fluxes of $\mathrm{CO}_{2}$ at the land-atmosphere boundary and in doing so models vegetation as a dynamic component of the climate system. It models photosynthesis, autotrophic respiratory fluxes from its three living vegetation components (leaves, stem, and roots, denoted by $L, S$, and $R$, respectively) and heterotrophic respiratory fluxes from its two dead carbon components (litter and soil carbon, denoted by $D$ and $H$, respectively). The flow of carbon through these five carbon pools is explicitly tracked, which allows the calculation of the amount of carbon in these pools as prognostic variables. Disturbance through fire and land use change are also modelled. CTEM cannot operate without coupling to CLASS. Its photosynthesis module operates at the same time step as CLASS and requires estimates of net radiation and soil moisture from CLASS. In return, CTEM provides CLASS with dynamically simulated structural attributes of vegetation which are functions of the driving meteorological data. The amount of carbon in the leaves, stem and root components is used to estimate structural attributes of vegetation. The leaf area index (LAI) is calculated from leaf biomass using PFT-dependent specific leaf area (SLA, $\left.\mathrm{m}^{2}(\mathrm{Kg} \mathrm{C})^{-1}\right)$, which determines the area of leaves that can be constructed per unit leaf carbon biomass (Arora and Boer, 2005a); vegetation height is calculated based on stem biomass for tree PFTs and LAI for grass PFTs (Arora and Boer, 2005a); and rooting depth is calculated based on root biomass (Arora and Boer, 2003). Other than photosynthesis, all terrestrial ecosystem processes in CTEM are modelled at a daily time step. CTEM models its terrestrial ecosystem processes for nine PFTs that map directly to the PFTs used by CLASS. Needleleaf trees in CTEM are divided into deciduous and evergreen for which terrestrial ecosystem processes are modelled separately, broadleaf trees are divided into cold and drought deciduous and evergreen types, and crops and grasses are divided into $\mathrm{C}_{3}$ and $\mathrm{C}_{4}$ versions based on their photosynthetic pathways. Version 2.0 of the model is explained in detail in Melton and Arora (2016), while version 2.1 is used here which amongst other minor changes includes all methane related processes discussed below.

The methane related processes implemented in CLASSCTEM build on the model's existing capabilities. Processes are implemented to be able to dynamically model the geographical distribution of wetlands and their methane emissions, methane emissions from fire and methane uptake by upland soils. The fractional coverage of wetlands in a grid cell is based on flat fraction within a grid cell with slope less than $0.2 \%$ and grid-averaged soil moisture. The methodology is explained in Appendix A.

\section{Wetland methane emissions}

The dominant controls on methane emissions in nature are considered to be (1) the position of the water table below which methane is produced due to anoxic decomposition of available organic matter and above which methane is oxidized, (2) the soil temperature which determines the rate of decomposition of organic matter, (3) the availability of organic matter itself, and (4) the pathway through which methane is transferred to the atmosphere (through soil via molecular diffusion, through stems of the vascular plants and through ebullition if the water table is above the soil surface). These factors are not completely independent and their relative importance changes as environmental conditions change 
(Walter and Heimann, 2000). The explicit consideration of these factors becomes more important as the spatial scale at which $\mathrm{CH}_{4}$ emissions are being modelled reduces. For example, X. Zhu et al. (2014) show that as the modelling spatial scale reduces from 100 to $5 \mathrm{~km}$, the dominant control on simulated wetland $\mathrm{CH}_{4}$ emissions switches from soil temperature to water table depth.

At the current operational resolution of around $2.81^{\circ}$ of CanESM (equal to about $310 \mathrm{~km}$ at the equator) we expect dominant controls on methane emissions to be soil moisture, soil temperature, and the availability of organic matter and this allows us to use the simple approach that we have used here. This approach also allows us to estimate $\mathrm{CH}_{4}$ emissions from wetlands without the use of wetland specific PFTs, as at large spatial scales net primary productivity (NPP) and heterotrophic respiration are governed by climate (Chengjin et al., 2016). $\mathrm{CH}_{4}$ emissions are simulated to occur over the wetland fraction of the grid cell. The simulated $\mathrm{CH}_{4}$ emissions from wetlands are calculated by scaling the heterotrophic respiratory flux $\left(R_{\mathrm{h}}\right)$ from model's litter $(D)$ and soil $(H)$ carbon pools, which itself depends on soil temperature, soil moisture, and the available organic matter. Heterotrophic respiration from the litter and soil carbon pools takes the following basic form, with the formulation explained in detail in Melton and Arora (2016).

$$
\begin{gathered}
R_{\mathrm{h}, i}=2.64 \times 10^{-6} \varsigma_{i} \mathrm{C}_{i} f_{i}\left(Q_{10}\right) f_{i}(\Psi), \\
i=D, H R_{\mathrm{h}}=R_{\mathrm{h}, D}+R_{\mathrm{h}, H}
\end{gathered}
$$

where $\varsigma_{i}$ represents the base respiration rate $(\mathrm{kgC}$ $\left.(\mathrm{kgC})^{-1} \mathrm{yr}^{-1}\right)$ at $15^{\circ} \mathrm{C}, \mathrm{C}_{i}$ is the amount of carbon in model's litter or soil carbon pool $\left(\mathrm{kg} \mathrm{C} \mathrm{m}^{-2}\right), f_{i}\left(Q_{10}\right)=$ $Q_{10}^{0.1\left(T_{i}-15\right)}$ is a $Q_{10}$ function that models the effect of temperature, $T_{i}$ is the temperature of litter or soil carbon pool $\left({ }^{\circ} \mathrm{C}\right)$, and $f_{i}(\Psi)$ is the function that reduces heterotrophic respiration when soils are too dry and too wet using the soil matric potential $(\Psi)$ (Melton et al., 2015). The constant $2.64 \times 10^{-6}$ converts units from $\mathrm{kg} \mathrm{C} \mathrm{m}^{-2} \mathrm{yr}^{-1}$ to $\mathrm{mol} \mathrm{CO}_{2} \mathrm{~m}^{-2} \mathrm{~s}^{-1}$.

Modelled $\mathrm{CH}_{4}$ emissions from wetlands, per unit area of a grid cell $\left(\mathrm{mol} \mathrm{CH}_{4} \mathrm{~m}^{-2} \mathrm{~s}^{-1}\right)$, are calculated as

$E_{\mathrm{w}}=R_{\mathrm{h}} f_{\mathrm{w}} \alpha_{\mathrm{w}} \delta_{s}$,

where $f_{\mathrm{w}}$ is the wetland fraction in a grid cell (see Appendix A), $\alpha_{\mathrm{w}}$ is the ratio of wetland to upland heterotrophic respiratory flux, and $\delta_{s}$ converts flux from $\mathrm{CO}_{2}$ to $\mathrm{CH}_{4}$ units but also takes into account that some of the $\mathrm{CH}_{4}$ flux is oxidized in the soil column before reaching the atmosphere. A value of 0.45 is used for $\alpha_{\mathrm{w}}$, as heterotrophic $\mathrm{CO}_{2}$ respiratory flux over lowlands is typically lower than over uplands, due to limitation by increased soil moisture including a high water table level. While the $f_{i}(\Psi)$ function in Eq. (1) does reduce heterotrophic respiration when soils are wet it does so using only the grid averaged soil moisture content. Wania et al. (2010) use a preferred value of $\delta_{s}$ equal to 0.1 and
Q. Zhu et al. (2014) found $\delta_{s}$ varies between 0.1 and 0.7 with a mean value of 0.23 when calibrating their model against data from 19 sites. A value of 0.135 is used for $\delta_{s}$ in this study. The product $\alpha_{\mathrm{w}} \delta_{s}$ thus equals 0.061 , which implies that for each $\mathrm{molCO}_{2} \mathrm{~m}^{-2} \mathrm{~s}^{-1}$ of heterotrophic respiratory flux $0.061 \mathrm{~mol} \mathrm{CH}_{4} \mathrm{~m}^{-2} \mathrm{~s}^{-1}$ is generated over unit area that is deemed wetland. At large spatial scales $\mathrm{CH}_{4}$ and $\mathrm{CO}_{2}$ heterotrophic respiratory fluxes are expected to be highly correlated, as to the first order they are both governed by temperature and the amount of organic matter available for decomposition (Dalva et al., 2001; Q. Zhu et al., 2014). In addition, as the spatial scale increases it is possible to ignore the effect of water table depth as X. Zhu et al. (2014) illustrate.

\section{Fire methane emissions}

Fire in CLASS-CTEM is modelled using an intermediate complexity scheme, which represents both natural and human-caused fires, and accounts for all elements of the fire triangle: fuel load, combustibility of fuel, and availability of ignition sources. The fire module accounts for both natural fires caused by lightning and anthropogenic fires which are the result of ignitions caused by humans expressed as a function of population density. Increasing population density increases human-caused fire ignitions but also increases suppression of fire. The suppression of fire represents fire-fighting efforts, landscape fragmentation, and other processes which leads to a reduction in area burned and is also modelled as a function of population density. The original fire parametrization is described in Arora and Boer (2005b), which has since been adapted and used in several other DGVMs (Kloster et al., 2010; Li et al., 2012; Migliavacca et al., 2013). The fire module in CTEM v. 2.1 incorporates changes suggested in these studies as well as several new improvements which are summarized in detail in Melton and Arora (2016). The approach has been evaluated at the global scale in Arora and Melton (2018) who assess how reduction in global wildfire emissions since the 1930s leads to an enhanced land carbon sink. The two primary outputs from the fire module are fraction of area burned per grid cell and dry organic biomass burned per unit area $\left(\mathrm{gC} \mathrm{m}^{-2}\right)$. The dry organic matter burned is then multiplied by corresponding emissions factors to obtained emissions $\left(\mathrm{g} \mathrm{species}^{-2}\right)$ for several species of trace gases and aerosols including methane $\left(\mathrm{CO}_{2}, \mathrm{CO}, \mathrm{CH}_{4}, \mathrm{H}_{2}, \mathrm{NHMC}, \mathrm{NO}_{x}, \mathrm{~N}_{2} \mathrm{O}\right.$, total particulate matter, particulate matter less than $2.5 \mu \mathrm{m}$ in diameter, and black and organic carbon). These emissions factors are based on an updated set by Andreae and Merlet (2001) listed in Tables 3 and 4 of Li et al. (2012).

\section{Soil uptake of methane}

The methane uptake over soil occurs over the unsaturated (upland) fraction of a grid cell that is not deemed wetland. The parameterization is based on an exact solu- 
tion of the one-dimensional diffusion-reaction equation in the near-surface (top) soil layer and described in detail in Curry (2007). Briefly, the methane uptake by soil is a function of diffusion of methane into soil (which depends on atmospheric methane concentration) and its subsequent oxidation by microbes. The diffusion of methane into the soil depends primarily on air filled porosity of the soil and increases as the pore volume filled by liquid and frozen moisture decreases. The oxidation of methane by microbes is a function of both soil moisture and temperature. Oxidation preferably occurs when soils are neither too dry (when microbial activity is limited by low soil moisture) nor too wet (when microbes are deprived of oxygen). Warmer temperatures favour oxidation of methane in soil and oxidation increases by about four times as soil temperature increases from 0 to $27.5^{\circ} \mathrm{C}$. Finally, the inhibition of methane uptake in cultivated soils is accounted for by a linear factor that reduces oxidation as crop fraction in a grid cell increases.

\subsubsection{Forcing data for the CLASS-CTEM model}

The CLASS-CTEM model is driven with meteorological data and atmospheric $\mathrm{CO}_{2}$ and $\mathrm{CH}_{4}$ concentrations. The model also requires geophysical fields for the fractional coverage of nine CTEM PFTs, soil texture, and depth to bedrock. The meteorological data are based on version 7 of the Climate Research Unit - National Centre for Environmental Prediction (CRU-NCEP) reanalysis dataset (Nicholas Viovy, personal communication, 2012). The meteorological variables (surface temperature, pressure, precipitation, wind, specific humidity, and incident short-wave and long-wave radiation fluxes) are available at a spatial resolution of $0.5^{\circ} \times 0.5^{\circ}$ and at a 6-hourly time interval for the period 1901-2015. These data are regridded to a spatial resolution of $2.81^{\circ}$ and temporally to a $30 \mathrm{~min}$ time step to drive the CLASS-CTEM model. Temperature, pressure, wind, specific humidity, and long-wave radiation are linearly interpolated in time while short-wave radiation is assumed to change with the solar zenith angle with maximum radiation occurring at solar noon. Following Arora (1997) the 6-hourly precipitation amount $\left(P, \mathrm{~mm}(6 \mathrm{~h})^{-1}\right)$ is used to estimate the number of wet half-hours in a given 6-hour period and the 6-hourly precipitation amount is randomly distributed over these wet half-hours. Figure B1 in Appendix B shows the annual landaveraged temperature and precipitation (excluding Antarctica) as derived from the CRU-NCEP data. Both temperature and precipitation show an overall increase over the 20th century that continues into the 21 st century, associated with the changing climate.

The land cover data are used by the model to specify the fractional coverage of CTEM's nine PFTs in each grid cell. These data are based on a geographical reconstruction of the historical land cover driven by the increase in crop area (Arora and Boer, 2010) but using the crop area data based on the LUH2 v1h version of the Hurtt et al. (2006) land cover product. The final data set consists of the fractional coverage of CTEM's nine PFTs for the period 1850-2015 at the global scale and at $2.81^{\circ}$ spatial resolution. The increase in crop area over the historical period leads to decrease in area of natural vegetation thus leading to deforestation. A fraction of deforested vegetation is burned but deforested biomass is also converted to paper and wood products which decompose over time leading to land use change emissions. These processes are described in detail in Arora and Boer (2010). In context of terrestrial methane budget, an increase in crop area leads to lower methane uptake by soil over the cultivated fraction of a grid cell.

The globally averaged atmospheric $\mathrm{CO}_{2}$ and $\mathrm{CH}_{4}$ concentrations used to drive the model are obtained from the data sets put together for the sixth phase of the Coupled Model Intercomparison Project (CMIP6) and available from input4MIPs web site (https://esgf-node.llnl.gov/ projects/input4mips/, last access: April 2017). These data are shown in Fig. B2.

\subsubsection{Observation and model-based data for CLASS-CTEM evaluation}

In addition to evaluating the CLASS-CTEM simulated methane emissions from wetlands, fire and methane uptake by soils in the context of the one-box atmospheric $\mathrm{CH}_{4}$ model as mentioned in Sect. 2.2 below, we also evaluate simulated present-day wetland extent and all modelled methane fluxes directly against other model and observation-based estimates.

The CLASS-CTEM simulated wetland extent is compared against two data sets: the wetland data from the Global Lakes and Wetlands Database (GLWD; Lehner and Döll, 2004) and a new product that is formed by merging remote sensing based observations of daily surface inundation from the Surface Water Microwave Product Series (SWAMPS; Schroeder et al., 2015) with the static inventory of wetland area from the GLWD. The derivation of the second product is explained in detail in Poulter et al. (2017). SWAMPS provides estimates of fractional surface water based on data from multiple passive and active microwave satellite missions. While open water (e.g. rivers, lakes, and ocean) and inundated wetlands comprising of open plant canopies are mapped by satellites, inundation beneath closed forest canopies, and exposed wetlands with water table below the surface cannot be mapped. However, satellite data are able to provide the seasonal cycle which static data sets like GLWD cannot. The merged SWAMPS-GLWD product attempts to overcome limitations of both individual data sets.

The simulated present-day methane emissions from wetlands and fire, and methane uptake by soil, are compared to top-down estimates compiled by Saunois et al. (2016). We also compare the anthropogenic emissions we have used within the framework of one-box atmospheric methane model (Sect. 2.2) with estimates from Saunois et al. (2016). 
Finally, we also evaluate the model regionally over the West Siberian lowlands (WSL). This region is chosen because inversion-based methane fluxes are readily accessible over the region, which were compiled and documented for the WETCHIMP-WSL intercomparison project (Bohn et al., 2015). We compare simulated wetland extent and wetland methane emissions with observation- and inversionbased results from Bousquet et al. (2011), Kim et al. (2011), and Winderlich (2012) and participating models in the Wetland and Wetland $\mathrm{CH}_{4}$ Intercomparison of Models Project (WETCHIMP, Melton et al., 2013) focused on the West Siberian lowlands region (WETCHIMP-WSL) (Bohn et al., 2015). Of these the Kim et al. (2011) and Winderlich (2012) are regional inversions. Kim et al. (2011) used wetland methane emissions from Glagolev et al. (2010) at $1^{\circ}$ spatial resolution as their prior and used the NIES-TM atmospheric transport model for the period 2002-2007. They derived climatological monthly wetland emissions optimized to match atmospheric methane concentrations obtained by aircraft sampling. Winderlich (2012) used the Kaplan (2002) wetland inventory for prior wetland emissions with the TM3STILT global inversion system for year 2009. Their posterior monthly wetland emissions were uniquely determined for each grid cell within their domain at $1^{\circ}$ spatial resolution and optimized to match atmospheric methane concentrations measured at four tower observation sites located between 58 and $63^{\circ} \mathrm{N}$. The Bousquet et al. (2011) is a global inversion but uses two priors, the first based on the Matthews and Fung (1987) emissions inventory and the second based on Kaplan (2002). Bousquet et al. (2011) inversion used the Laboratoire de Météorologie Dynamique general circulation model (LMDZ) atmospheric transport model at a $3.75^{\circ} \times 2.5^{\circ}$ grid and estimated monthly methane emissions at a $1^{\circ}$ spatial resolution for the period 1993-2009. Being a global inversion, they optimized atmospheric concentrations relative to global surface observations at several flask stations for methane but also other trace gases. For wetland extent, we compare the CLASS-CTEM simulated wetland extent over the WSL region with models participating in the WETCHIMP-WSL intercomparison, and GLWD and SWAMPS + GLWD products mentioned above but also the Global Inundation Extent from Multi-Satellites (GIEMS; Prigent et al., 2007; Papa et al., 2010) derived from visible and near-infrared and active and passive microwave sensors for the period 1993-2004. In addition, we also use the estimate from Peregon et al. (2009) who used a regional wetland typology map further refined by satellite image classifications to calculate the wetland extent in the WSL region.

\subsection{Atmospheric methane - one-box model, anthropogenic emissions, and lifetime}

\subsubsection{One-box model of atmospheric methane}

A one-box model of atmospheric $\mathrm{CH}_{4}$ is used to evaluate the time evolution of simulated methane emissions from wetlands $\left(E_{\mathrm{w}}\right)$, methane emissions from fire $\left(E_{\mathrm{f}}\right)$ and the soil uptake of methane $\left(S_{\text {soil }}\right)$ over the period 1850-2008. The model describes the changes in burden of atmospheric $\mathrm{CH}_{4}$ $(B)$ as a balance of surface emissions (consisting of natural, $E_{\mathrm{N}}$, and anthropogenic emissions, $\left.E_{\mathrm{A}}\right)$ and the atmospheric $\left(S_{\text {atmos }}\right)$ and surface soil sinks $\left(S_{\text {soil }}\right)$.

$\frac{\mathrm{d} B}{\mathrm{~d} t}=E_{\mathrm{N}}(t)+E_{\mathrm{A}}(t)-S_{\text {atmos }}(t)-S_{\text {soil }}(t)$,

where $t$ is the time and Eq. (3) is applied at an annual time step. The atmospheric $\mathrm{CH}_{4}$ burden $\left(B, \mathrm{Tg} \mathrm{CH}_{4}\right)$ equals 2.78 times $\left[\mathrm{CH}_{4}\right]$ (represented in units of parts per billion, ppb) (Denman et al., 2007). The distinction between natural and anthropogenic emissions is not straightforward for fire, which contains emissions due to both natural and humancaused fires. For comparison with Saunois et al. (2016) global $\mathrm{CH}_{4}$ budget (as shown later in Sect. 3) we consider all emissions from fire as anthropogenic, although the CLASSCTEM model calculates fire emissions due both to lightning and human-caused ignitions. Natural emissions $\left(E_{\mathrm{N}}=\right.$ $\left.E_{\mathrm{w}}+E_{\mathrm{o}}\right)$ consist of modelled wetlands emissions $\left(E_{\mathrm{w}}\right)$ and emissions from other natural sources $\left(E_{\mathrm{o}}\right)$ (including termites, geological sources, wild animals, and freshwater), which we specify at $25 \mathrm{Tg} \mathrm{CH}_{4} \mathrm{yr}^{-1}$ (consistent with, but towards, the lower end of the range natural emissions, 21$130 \mathrm{Tg} \mathrm{CH}_{4} \mathrm{yr}^{-1}$, as deduced by top-down approaches summarized in Saunois et al., 2016). The reason for specifying $E_{\mathrm{o}}$ at $25 \mathrm{Tg} \mathrm{CH}_{4} \mathrm{yr}^{-1}$ is discussed later in Sect. 4. Anthropogenic emissions $\left(E_{\mathrm{A}}=E_{A \text { excl fire }}+E_{\mathrm{f}}\right)$ consist of specified emissions from all anthropogenic sources excluding fire $\left(E_{A \text { excl fire }}\right)$ and fire emissions, which we explicitly model $\left(E_{\mathrm{f}}\right)$. Estimation of anthropogenic emissions excluding those from fire and biomass burning ( $\left.E_{\mathrm{A} \text { excl fire }}\right)$ data are explained in Sect. 2.2.2.

The atmospheric sink $S$ is calculated as a first-order loss process from methane's lifetime $\tau_{\text {chem }}$ in the atmosphere as $S_{\text {atmos }}(t)=B(t)\left[1-\exp \left(-1 / \tau_{\text {chem }}(t)\right)\right]$. An estimate of $\tau_{\text {chem }}$ is obtained from the Canadian Middle Atmosphere Model (CMAM) with chemistry and compared to an observation-based estimate from Prather et al. (2012) as later shown in Sect. 2.2.3. With $S_{\text {atmos }}$ represented in terms of $\tau_{\text {chem }}$ Eq. (3) can be rewritten as

$$
\begin{aligned}
B(t+\Delta t)= & B(t)-B(t)\left[1-\exp \left(-1 / \tau_{\text {chem }}(t)\right)\right] \\
& +\left(E_{\mathrm{N}}(t)+E_{\mathrm{A}}(t)-S_{\text {soil }}(t)\right) \Delta t \\
= & B(t)\left[\exp \left(-1 / \tau_{\text {chem }}(t)\right)\right]+\left(E_{\mathrm{N}}(t)\right. \\
& \left.+E_{\mathrm{A}}(t)-S_{\text {soil }}(t)\right) \Delta t
\end{aligned}
$$


where $\Delta t=1$ year. Equation (4) can be used to evaluate simulated natural methane emissions $E_{\mathrm{N}}$ in two ways. First, when all the terms on the right hand side of Eq. (4), including an initial value of $B(t)$, are known, then the time evolution of $B$ can be calculated and compared to its observation-based estimate. Second, if the time evolution of $B$ is specified based on observations of methane concentration in the atmosphere, then the value of $\tau_{\text {chem }}$ required to satisfy Eq. (4) can be calculated (see Eq. 5) and compared its observation-based estimate e.g. from Prather et al. (2012).

$\tau_{\text {chem }}(t)=-\frac{1}{\log \left(\frac{B(t+\Delta t)-\left(E_{\mathrm{N}}(t)+E_{\mathrm{A}}(t)-S_{\text {soil }}(t)\right) \Delta t}{B(t)}\right)}$

In Sect. 3, we have used both these methodologies to assess CLASS-CTEM simulated methane emissions from wetlands $\left(E_{\mathrm{w}}\right)$, methane emissions from fire $\left(E_{\mathrm{f}}\right)$, and the soil uptake of methane $\left(S_{\text {soil }}\right)$. Note that Eq. (4) does not include any term for oceanic methane emissions. Saunois et al. (2016) report a range of $0-5 \mathrm{TgCH}_{4} \mathrm{yr}^{-1}$, with a mean value of $2 \mathrm{Tg} \mathrm{CH}_{4} \mathrm{yr}^{-1}$ for oceanic methane emissions. Given the large uncertainty in other components of the global methane budget, and the small magnitude of oceanic methane emissions, we have ignored this term.

Equation (3) may also be used to calculate pre-industrial methane concentration assuming atmospheric methane concentration was in equilibrium with pre-industrial emissions and sinks, i.e. by setting $\frac{\mathrm{d} B}{\mathrm{~d} t}=0$, which yields

$E_{\mathrm{N}}(t)+E_{\mathrm{A}}(t)=S_{\text {atmos }}(t)+S_{\text {soil }}(t)$.

Substituting $S_{\text {atmos }}(t)=B(t)\left[1-\exp \left(-1 / \tau_{\text {chem }}(t)\right)\right]$ similar to as was done in Eq. (4) and solving for $B(t)$ gives

$B(t)=\frac{E_{\mathrm{N}}(t)+E_{\mathrm{A}}(t)-S_{\text {soil }}(t)}{1-\exp \left(-1 / \tau_{\text {chem }}(t)\right)}$.

Using values of sources and sinks and $\tau_{\text {chem }}$ corresponding to year 1850 , for example, yields $B(t)\left(\mathrm{Tg} \mathrm{CH}_{4}\right)$, which when divided by 2.78 yields $\left[\mathrm{CH}_{4}\right]$ in ppb for 1850 .

\subsubsection{Anthropogenic methane emissions}

The time evolution of global $E_{\mathrm{A}}$ (used in Eq. 4) for the 18502008 period is based on two data sets. The first data set is the decadal representative concentration pathway (RCP) anthropogenic methane emissions data set (version 2.0.5) available at $0.5^{\circ}$ spatial resolution for the period 1850-2000 and provided for the fifth phase of the coupled model Intercomparison project (CMIP5) by the International Institute for Applied Systems Analysis (IIASA) (http://www.iiasa.ac.at/ web-apps/tnt/RcpDb, last access: October 2014). The value for the first year of each decade is assumed to correspond to the rest of the decade. So the 1850 value corresponds to the 1850-1859 decade, the 1860 value corresponds to the 1860-1869 decade, and so on. The second anthropogenic methane emissions data set is part of version 4.2 of the Emission Database for Global Atmospheric Research (EDGAR, $\mathrm{http} / / /$ edgar.jrc.ec.europa.eu/overview.php? $\mathrm{v}=42$, last access: October 2014) available at $0.1^{\circ}$ spatial resolution and available for the period 1970-2008. These data sets were selected because the RCP data set provides the anthropogenic methane emissions going back to 1850 and the EDGAR data set provides the anthropogenic methane emissions for more recent years since 1970 . The EDGAR data set was also chosen because amongst the recent anthropogenic data sets this is the only data set which provides gridded anthropogenic methane emissions at an annual time scale (see Table 1 of Saunois et al., 2016).

These two data sets are blended (or harmonized) to obtain a consistent time series of annual global anthropogenic methane emissions for the period 1850-2008. First the RCP and EDGAR data are regridded from their 0.5 and $0.1^{\circ}$ spatial resolutions, respectively, to the $2.81^{\circ}$ resolution at which the model is applied. Next, all non-biomass burning emission categories are added separately in both data sets to obtain total anthropogenic emissions for each data set. The emissions categories in both data sets are somewhat different as shown in Table 1. Emissions from fire and biomass burning are excluded because CLASS-CTEM simulates $\mathrm{CH}_{4}$ emissions from fire explicitly. As our framework requires only total anthropogenic methane emissions (excluding biomass burning) the different emissions categories in the two data sets do not matter. The wetland emissions from rice paddies, which we do not explicitly model, are included in the specified anthropogenic emissions (in category 11 of the EDGAR data set and category 1 of the RCP data set as shown in Table 1). Equation (8) summarizes this harmonization methodology for a given grid cell.

$$
\begin{aligned}
E_{\mathrm{A}, \text { RCP adjusted }}(t)= & E_{A, \mathrm{RCP}}(t)+\frac{t-1850}{1970-1850} \\
& \left(E_{\mathrm{A}, \text { EDGAR }}(1970)-E_{\mathrm{A}, \mathrm{RCP}}(1970)\right),
\end{aligned}
$$

where $E_{\mathrm{A}, \mathrm{RCP}}$ and $E_{\mathrm{A}, \text { EDGAR }}$ represent annual anthropogenic methane emissions (excluding biomass burning) in the RCP and EDGAR data sets, respectively, $E_{\mathrm{A}, \mathrm{RCP} \text { adjusted }}$ represent the adjusted RCP emissions and $t$ is the time in years from 1850 to 1970 . The harmonization algorithm adjusts the annual total anthropogenic methane emissions in the RCP data, for each $2.81^{\circ}$ grid cell, from 1850 to 1970 such that by the time RCP emissions reach 1970 they are the same as the EDGAR's total emissions excluding biomass burning. As a result of this harmonization, the largest change is made to RCP emissions for 1970 and the smallest change is made for year 1851. The RCP emissions for 1850 are not changed. The final harmonized time series for $E_{\mathrm{A}}$ is obtained by concatenating $E_{\mathrm{A}, \mathrm{RCP} \text { adjusted }}$ for the period 1850 to 1970 and $E_{\mathrm{A}, \mathrm{EDGAR}}$ for the period from 1971 to 2008.

Figure 1a shows the harmonized time series of global anthropogenic methane emissions along with the decadal RCP 
Table 1. Emissions categories for EDGAR and RCP anthropogenic methane emissions.

\begin{tabular}{llll}
\hline \multicolumn{2}{c}{ EDGAR } & \multicolumn{2}{c}{$\begin{array}{c}\text { RCP } \\
\text { Non-biomass burning categories }\end{array}$} \\
\hline 1. & Energy manufacturing transformation & 1. & Agricultural sector \\
2. & Non-road transportation & 2. & Agricultural waste burning \\
3. & Road transportation & 3. & Residential and commercial combustion \\
4. & Residential & 4. & Energy production and distribution \\
5. & Fugitive from solid & 5. & Industrial processes and combustion \\
6. & Oil production and refineries & 6. & Land transport emissions \\
7. & Gas production and distribution & 7. & Waste treatment and disposal \\
8. & Industrial processes and product use & 8. & Shipping \\
9. & Enteric fermentation & & \\
10. & Manure management & & \\
11. & Agricultural soils & & \\
12. & Agricultural waste burning & & \\
13. & Soil waste disposal & & \\
14. & Waste waster & & \\
15. & Fossil fuel fires &
\end{tabular}

Biomass burning categories

$\begin{array}{lll}\text { 16. Large scale biomass burning } & 9 . & \text { Biomass burning from forest fires } \\ & \text { 10. } & \text { Biomass burning from grass fires }\end{array}$
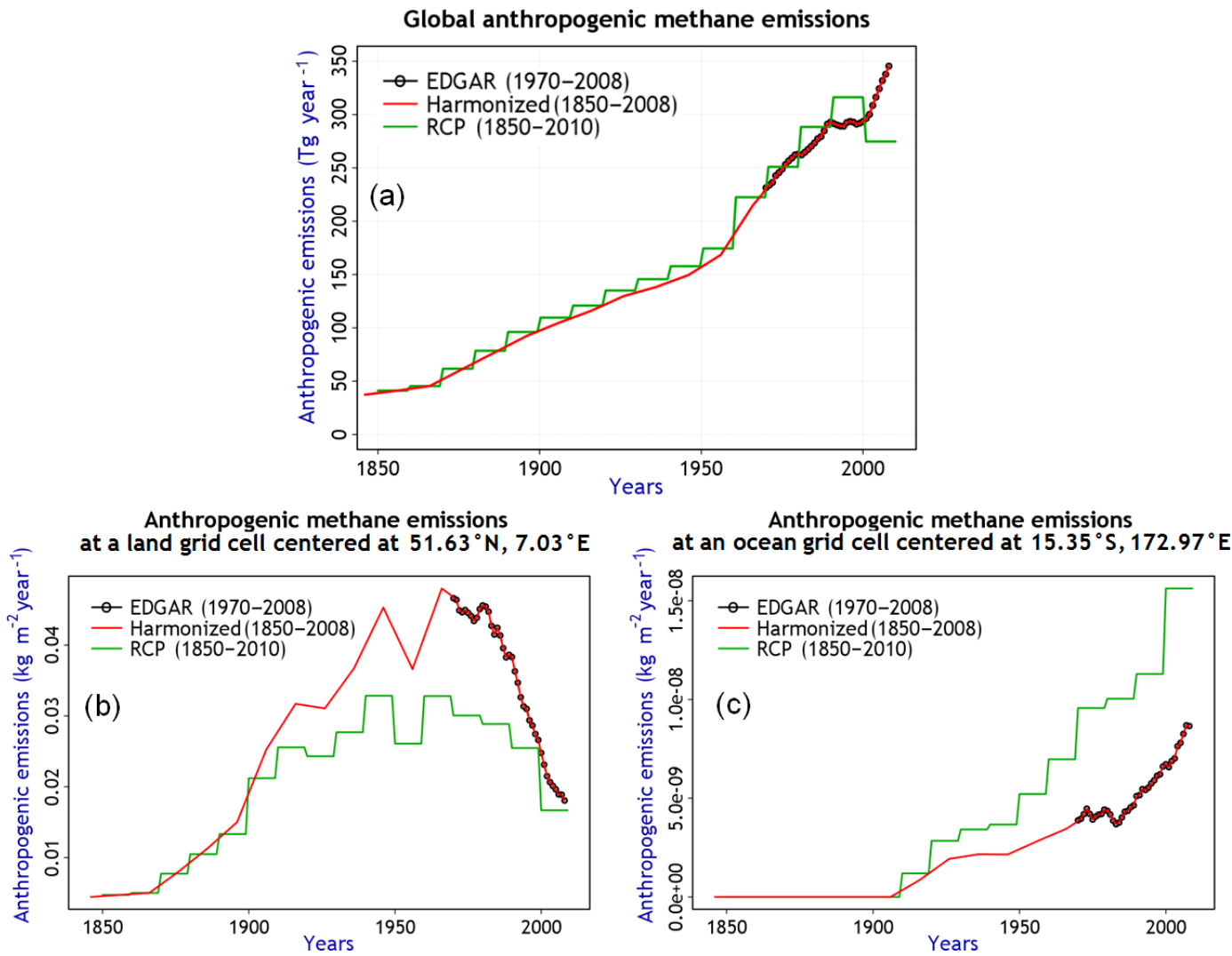

Figure 1. Comparison of RCP, EDGAR and their harmonized annual global anthropogenic methane emissions (a) excluding biomass burning. $(\mathbf{b}, \mathbf{c})$ illustrate the harmonization technique for a land and an ocean grid cell, respectively. 
and annual EDGAR emissions (excluding biomass burning). The RCP and EDGAR emissions are fairly similar for the period 1970-1990 but are different after 1990. Figure 1b and c illustrate how the harmonization works for two selected grid cells based on Eq. (8). In Fig. 1b anthropogenic methane emissions are shown for a land grid cell where emissions first increase and then decrease. In Fig. 1c anthropogenic methane emissions are shown for an ocean grid cell, with six orders of magnitude lower emissions than the land grid cell, where emissions more or less continuously increase. In both case, the harmonization ensures that by 1970 the adjusted RCP emissions are same as the EDGAR emissions. Although for the purpose of using $E_{\mathrm{A}}$ in Eq. (4) only its global values are required, the methodology described here yields a continuous consistent gridded data set of anthropogenic methane emissions for the period of our analysis with no abrupt jumps.

\subsubsection{Lifetime of atmospheric methane}

To use Eq. (4), for evaluation of CLASS-CTEM simulated annual values of $E_{\mathrm{w}}, E_{\mathrm{f}}$ and $S_{\text {soil }}$ over the historical period, time-evolving annual values of $\tau_{\text {chem }}$ are required. We obtain values of $\tau_{\text {chem }}$ simulated by the Canadian Middle Atmosphere Model (CMAM). The CMAM is a fully interactive chemistry-climate model (CCM) that is based on a vertically extended version of the third generation Canadian Atmospheric General Circulation Model with a model lid at $95 \mathrm{~km}$ (Scinocca et al., 2008). The model contains a description of the important physical and chemical processes of the stratosphere and mesosphere and has been extensively assessed against observations through participation in two phases of the Chemistry-Climate Model Validation (CCMVal) activity (Eyring et al., 2006; SPARC CCMVal, 2010). Of more importance for methane, the chemistry has been extended throughout the troposphere by including cloud corrections on clear-sky photolysis rates, emissions of ozone precursors $\mathrm{CO}$ and $\mathrm{NO}_{x}\left(\mathrm{NO}+\mathrm{NO}_{2}\right)$ including emissions of $\mathrm{NO}_{x}$ from lightning, hydrolysis on specified tropospheric sulfate aerosols and interactive wet and dry deposition. Note that the chemical mechanism currently used in CMAM has not yet been extended to include the chemistry of non-methane hydrocarbons important in the troposphere; only methane chemistry is considered.

Results from CMAM with tropospheric chemistry have been submitted to the Atmospheric Chemistry and Climate Model Intercomparison Project (ACCMIP) (Lamarque et al., 2013). The experimental design for ACCMIP involved timeslice simulations at various points in time between 1850 and 2100 , with simulations for year 2000 conditions used for assessing the model chemical climate against available presentday observations. The ACCMIP intercomparison found that the CMAM produced estimates of tropospheric chemical quantities that fell well within the range of current generation CCMs. For example, the present-day tropospheric ozone

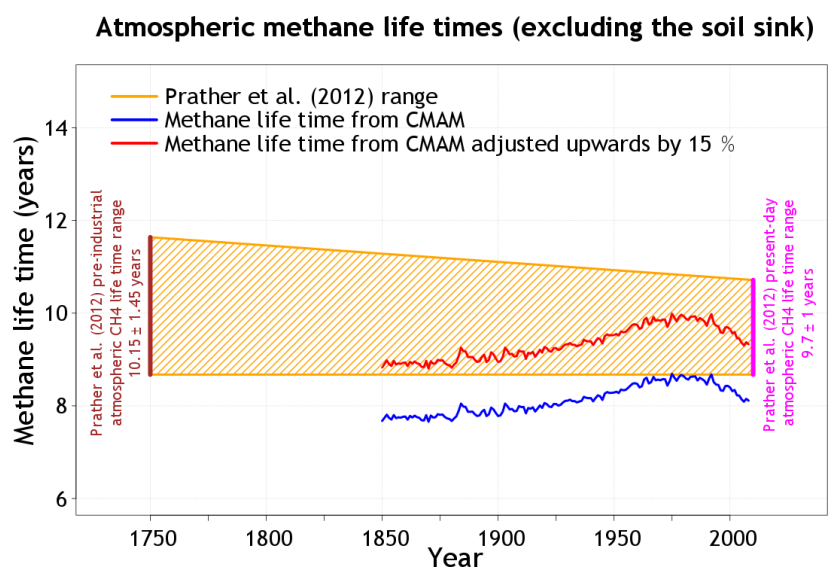

Figure 2. Comparison of atmospheric methane lifetime obtained from the Canadian Middle Atmosphere Model (CMAM) for the period 1850-2010 with observation-based estimates from Prather et al. (2012) but excluding the soil sink as explained in Sect. 2.2.3.

burden from CMAM was $323 \mathrm{Tg}$, vs. a multi-model mean of $337 \pm 23 \mathrm{Tg}$, where the range is given as one standard deviation across the 15 participating models (Young et al., 2013). The present-day methane lifetime to reaction with $\mathrm{OH}$ in the troposphere was found to be 9.4 years, again well within the range of ACCMIP models of $9.7 \pm 1.5$ years (Naik et al., 2013). However, like the majority of ACCMIP models, the CMAM predicts a too fast removal of $\mathrm{CH}_{4}$ by $\mathrm{OH}$ as compared with our best-estimate from methyl-chloroform decay of 11.2 \pm 1.3 years (Prather et al., 2012). As described further below, the calculated $\mathrm{CH}_{4}$ lifetime to chemical loss from CMAM is thus scaled to agree with observationally based estimates before being used in the one-box atmospheric model of $\mathrm{CH}_{4}$.

Time-dependent values of $\tau_{\text {chem }}$ are derived from a simulation over the 1850-2014 period that uses specified seasurface temperatures and sea-ice from one member of the five-member historical ensemble performed by CanESM2 for the CMIP5. Data for 2006-2014 was taken from a continuation of that simulation for the RCP 6.0 scenario. Specified anthropogenic and biomass burning emissions of $\mathrm{CO}$ and $\mathrm{NO}_{x}$ were taken from the CMIP5 historical database (Lamarque et al., 2010) up to 2000 and for the RCP 6.0 scenario to 2014. Specified concentrations of long-lived greenhouse gases were from Meinshausen et al. (2011), following RCP 6.0 from 2006-2014. Specified stratospheric aerosol surface area density fields, used to account for the effects of large volcanic eruptions, was based on the 1960-2010 database created for the Chemistry Climate Model Initiative (CCMI) extended back to 1850 following the approach described in Neely III et al. (2016). Solar variability was included by calculating the wavelength-resolved daily variability relative to the long-term average (June 1976-January 2007) from the recommended CMIP6 database (Matthes et al., 2017). 
The observation-based estimate of $\tau_{\text {chem }}$ is obtained from Prather et al. (2012) who calculate $\tau_{\mathrm{CH}_{4}}$ based on Eq. (9) as

$$
\frac{1}{\tau_{\mathrm{CH}_{4}}}=\frac{1}{\tau_{\mathrm{OH}}}+\frac{1}{\tau_{\text {strat }}}+\frac{1}{\tau_{\text {trop }-\mathrm{Cl}}}+\frac{1}{\tau_{\text {soil }}}=\frac{1}{\tau_{\text {chem }}}+\frac{1}{\tau_{\text {soil }}},
$$

where $\tau_{\mathrm{OH}}$ (present day value of 11.2 years), $\tau_{\text {strat }}$ (120 years $), \tau_{\text {trop}-\mathrm{Cl}}(200$ years $)$, and $\tau_{\text {soil }}(150$ years $)$ are the lifetimes associated with the destruction of $\mathrm{CH}_{4}$ by tropospheric $\mathrm{OH}$ radicals, loss in the stratosphere, reaction with tropospheric chlorine and uptake by soils, respectively, which yields a present day (corresponding to year 2010) value of $\tau_{\mathrm{CH}_{4}}$ as $9.1 \pm 0.9$ years. $\tau_{\text {chem }}$ is the methane life time associated with all chemical processes in the atmosphere. For the pre-industrial period (corresponding to year 1750), Prather et al. (2012) estimate $\tau_{\mathrm{CH}_{4}}$ as $9.5 \pm 1.3$ years assuming $\tau_{\mathrm{OH}}$ to be equal to 11.76 years (based on Atmospheric Chemistry and Climate Model Intercomparison Project (ACCMIP) results; Voulgarakis et al., 2013) and lifetimes associated with other processes are assumed to stay the same. In our study, the methane soil sink is explicitly simulated in the CLASSCTEM framework and this corresponds to the term $\frac{1}{\tau_{\text {soil }}}$ in Eq. (9). The remaining terms in Eq. (9) all correspond to atmospheric processes. Removing the $\frac{1}{\tau_{\text {soil }}}$ term in Eq. (9) gives us an observation-based estimate of $\tau_{\text {chem }}$ making it consistent with CMAM's methane lifetime corresponding only to atmospheric processes and increases the observation-based estimates of pre-industrial and present-day atmospheric $\mathrm{CH}_{4}$ lifetimes to $10.15 \pm 1.45$ years and $9.7 \pm 1.0$ years, respectively.

Figure 2 compares the $\tau_{\text {chem }}$ values from CMAM with its observation-based estimate from Prather et al. (2012) and shows that CMAM based estimates are biased low and outside the uncertainty range of observation-based estimates, as mentioned earlier. When used in the one-box model of atmospheric methane, the lower than observed $\tau_{\text {chem }}$ values will inevitably lead to a higher than observed atmospheric sink $\left(S_{\text {atmos }}\right)$ and thus lower than observed atmospheric methane concentration even if all the other flux terms $\left(E_{\mathrm{N}}, E_{\mathrm{A}}\right.$, and $S_{\text {soil }}$ ) in Eq. (5) are realistic. Therefore, we adjust the CMAM derived values of $\tau_{\text {chem }}$ upwards by $15 \%$ so that they lie within the uncertainty range of observation-based estimates of the $\tau_{\text {chem }}$ as derived by Prather et al. (2012). These adjusted values of $\tau_{\text {chem }}$ are also shown in Fig. 2 .

\subsection{The experimental setup}

\subsubsection{Equilibrium pre-industrial simulation}

The equilibrium pre-industrial simulation was initialized from zero biomass for all PFTs. The fractional coverages of CTEM's nine PFTs for the pre-industrial simulation are based on the land cover product described in Sect. 2.1.2 for 1850. The model was then driven with 1901-1925 CRUNCEP climate data cycled repeatedly until the model pools reach equilibrium. The early part of the 20 th century does not show any significant trends compared to the later part of the 20th century, as seen in Fig. B1 (Appendix B), so using the 1901-1925 data to spin up the model to equilibrium for 1850 conditions is reasonable. Atmospheric $\mathrm{CO}_{2}$ and $\mathrm{CH}_{4}$ concentration levels were set to $285 \mathrm{ppm}$ and $791 \mathrm{ppb}$, respectively, corresponding to their pre-industrial 1850 levels. This pre-industrial equilibrium simulation yields initial conditions for all CLASS-CTEM prognostic variables for the transient 1851-2015 simulation.

\subsubsection{Transient historical simulation}

The transient historical simulation is performed for the period 1851-2015 and its prognostic variables are initialized from the equilibrium pre-industrial simulation as mentioned above. For the period 1851 to 1900 of this simulation the model is driven with meteorological data from 1901-1925 twice, similar to what was done for spinning up the model for the pre-industrial simulation. For the period 1901-2015 the meteorological data corresponding to each year are used. Time varying concentrations of atmospheric $\mathrm{CO}_{2}$ and $\mathrm{CH}_{4}$ are specified for the period 1851-2015. The annual timevarying fractional coverages of $\mathrm{C}_{3}$ and $\mathrm{C}_{4}$ crop PFTs in each grid cell are based on LUH2 v1h version of the Hurtt et al. (2006) land cover product.

In this transient simulation, (1) wetland extent and its methane emissions respond to changes in climate but also increases in atmospheric $\mathrm{CO}_{2}$ concentration (which increases net primary productivity and thus heterotrophic respiration), (2) methane emissions from fire respond to changes in climate, atmospheric $\mathrm{CO}_{2}$ concentration, population density, and land use change, and (3) methane uptake by soil responds to climate, changes in atmospheric $\mathrm{CH}_{4}$ concentration and changes in crop fraction.

\section{Results}

We first show the results from the transient 1851-2015 simulation and evaluate the time-evolution of CLASS-CTEM simulated global natural methane fluxes over the historical period using the one-box model of atmospheric methane described in Sect. 2.2.1. This is followed by evaluation of model fluxes for the present day against observation-based estimates and for the WSL region using observation-based estimates and results from other models.

\subsection{Time evolution of simulated global natural methane fluxes}

Figure 3 shows the time evolution of simulated annual maximum wetland extent, methane emissions from wetlands and fire, and soil uptake by methane from the 1851-2015 transient historical simulation. In Fig. 3 (1) the simulated wetland methane emissions increase by $30 \%$ over the historical period from about 130 to $169 \mathrm{Tg} \mathrm{CH}_{4} \mathrm{yr}^{-1}$ from 1850 s to the present day (2000-2008), partly due to increase in wetland 


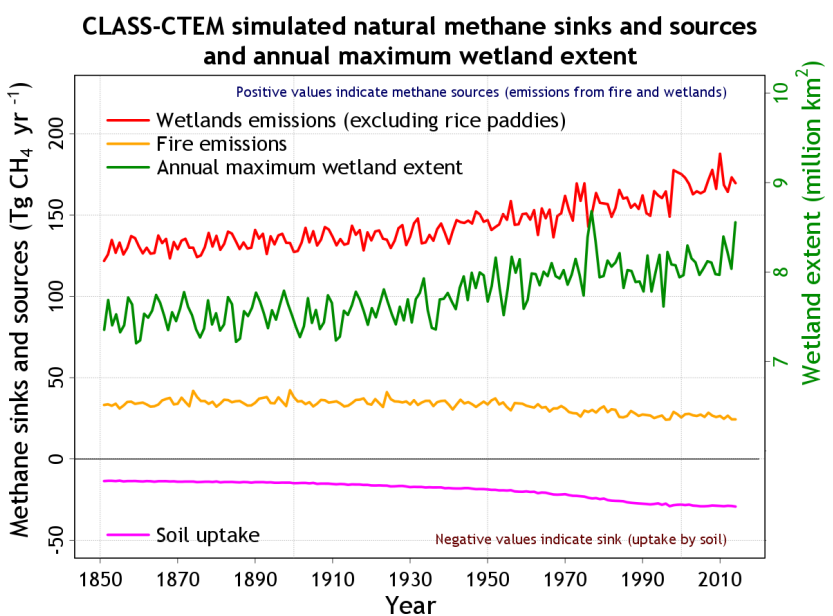

Figure 3. Time evolution of simulated natural methane fluxes (shown on the primary $y$ axis) and annual maximum wetland extent (shown on the secondary $y$ axis) by CLASS-CTEM for the 18512015 period in the transient historical simulation.

extent which increases by $8 \%$ from 7.5 to 8.1 million $\mathrm{km}^{2}$ from 1850 s to the present day, (2) the simulated fire methane emissions decrease from their 1850 s value by $20 \%$ from about 34 to $27 \mathrm{TgCH}_{4} \mathrm{yr}^{-1}$ for the present day, and (3) the soil methane uptake more than doubles from its 1850 s value of about 14 to $29 \mathrm{Tg} \mathrm{CH}_{4} \mathrm{yr}^{-1}$ for the present day.

The increase in wetland methane emissions over the historical period is due to an increase in the wetland area, driven by increase in precipitation seen in Fig. B1 (Appendix B), but also higher methane fluxes per unit area. The higher methane fluxes per unit area are caused by increase in atmospheric $\mathrm{CO}_{2}$ concentration which increases both net primary productivity and heterotrophic respiration over the historical period as shown in Fig. $\mathrm{C} 1$ in Appendix C. As wetland methane emissions are proportional to heterotrophic respiration $\left(R_{\mathrm{h}}\right)$ in Eq. (2), an increase in $R_{\mathrm{h}}$ also increases methane emissions from wetlands.

The decrease in methane emissions from wildfires is driven by a decrease in area burned, which itself is driven by an increase in crop area and population density over the historical period (Arora and Melton, 2018). The increase in cropland area decreases area burned by wildfires in the model, as croplands are not allowed to burn. In the real world cropland area also fragments the landscape, which affects the spread of fire. Direct anthropogenic influences on wildfires are more complex as accidental, as well as intentional, human-caused ignitions enhance wildfires, while anthropogenic suppression of wildfires decreases area burned and fire related emissions. Figure C2 (Appendix C) shows that the overall effect of increase in crop area and population density in the model is that area burned increases slightly up to about 1930, and then starts decreasing thereafter and this area burned pattern compares reasonably with the decadal charcoal index from the Global Charcoal Database version 3
(Marlon et al., 2008) for the full length of the historical simulation. Wind and smoke carry charcoal from fires and deposit it onto aquatic sediments and this forms the basis of sediment charcoal indices. The caveat with the comparison with sediment charcoal records is that they only provide a proxy for fire activity and indicate if fire activity is higher or lower relative to a point in time. Figure $\mathrm{C} 2$ also compares area burned with estimates from version 4.1s of the Global Fire Emissions Database (Randerson et al., 2012; Giglio et al., 2013) that are based on the satellite record and available only for the short 1997-2014 period. Model and observation-based average burned area over this 1997-2014 period are 483.4

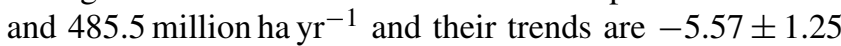
and $-3.43 \pm 1.05$ million ha $\mathrm{yr}^{-2}$, respectively. The negative trends indicate burned area has been decreasing.

Finally, the increase in methane uptake by soils is primarily the response to an increase in the atmospheric concentration of methane. Diffusion of methane into the soil is directly proportional to its atmospheric concentration (Curry, 2007) which more than doubles from around $790 \mathrm{ppb}$ in 1850 to around $1830 \mathrm{ppb}$ in 2015 (Fig. B2b).

\subsection{Evaluation of simulated global natural methane fluxes}

We first evaluate the CLASS-CTEM simulated global natural methane fluxes in a forward simulation where all the right hand side terms of Eqs. (3) and (4) are specified at an annual time step and the change in atmospheric methane burden $\frac{\mathrm{d} B}{\mathrm{~d} t}$ is calculated every year. Although the CRU-NCEP meteorological data are available to 2015 allowing us to perform offline CLASS-CTEM simulations up until 2015, the last year for which harmonized RCP-EDGAR emissions are available is 2008 . Therefore, we simulate the time evolution of atmospheric methane concentration for the period 1851-2008. In this forward calculation of atmospheric methane burden the one box model may be initialized using the observed 1850 methane concentration or using the 1850 concentration that is in equilibrium with 1850 sinks and sources. The latter is calculated by assuming $\frac{\mathrm{d} B}{\mathrm{~d} t}=0$ as illustrated in Eqs. (6) and (7). The numerator term in Eq. (7) $\left(E_{\mathrm{N}}(t)+E_{\mathrm{A}}(t)-S_{\text {soil }}(t)\right)$ for 1850 is $214.2 \mathrm{Tg} \mathrm{CH}_{4} \mathrm{yr}^{-1}$ (wetland emissions are 130.1, other natural emissions are specified at 25 , anthropogenic emissions are 39.5, fire emissions are 33.2, and soil uptake is 13.6). In Eq. (7), using an adjusted CMAM $\tau_{\text {chem }}$ value of 8.82 years (for 1850, red line in Fig. 2) yields an 1850 equilibrium $\left[\mathrm{CH}_{4}\right]$ for 1850 of $719 \mathrm{ppb}$ compared to its observation-based value of $791 \mathrm{ppb}$. In contrast, using the midrange value of $\tau_{\text {chem }}$ of 9.97 years based on Prather et al. (2012) yields equilibrium $\left[\mathrm{CH}_{4}\right]$ for 1850 of $808 \mathrm{ppm}$ which compares much better with its observation-based estimate of $791 \mathrm{ppm}$. An equilibrium methane concentration in 1850 that is lower than observed, when using adjusted CMAM $\tau_{\text {chem }}$, implies that the atmospheric methane sink is higher and associated with lower than observed atmospheric 

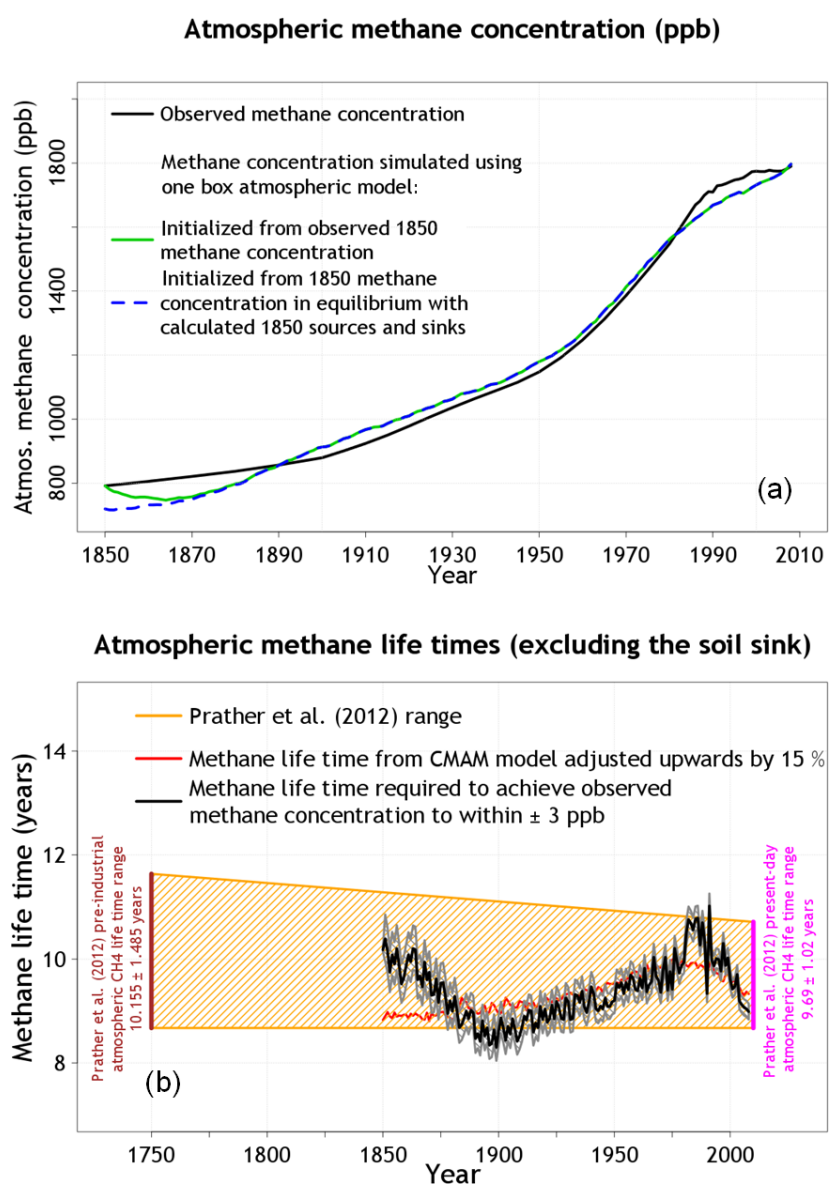

Figure 4. Comparison of simulated methane concentration over the historical period with its observation-based estimates (a). The simulation may be initialized from the 1850 observed methane concentration (solid green line) or from an 1850 concentration that is in equilibrium with 1850 specified methane sources and sinks (dashed blue line) as explained in Sect. 3.2. Panel (b) compares the methane lifetimes required to achieve the observed increase in methane concentration over the historical period (black line) to within $\pm 3 \mathrm{ppb}$ (shaded area between grey lines) with observation-based estimates of atmospheric methane lifetime based on Prather et al. (2012) and the adjusted atmospheric methane lifetime from CMAM.

methane lifetime in 1850. Indeed, the adjusted CMAM $\tau_{\text {chem }}$ for 1850 of 8.82 years is less than Prather et al. (2012) midrange estimate of 9.97 years but still within their uncertainty range as seen in Fig. 2. Regardless, as the lifetime of methane in the atmosphere is only around 10 years, the effect of initial conditions disappears by around 1870. This is shown in Fig. 4a, which compares the simulated evolution of atmospheric methane burden with its observations using the adjusted CMAM $\tau_{\text {chem. }}$. Figure $4 \mathrm{a}$ shows that overall the simulated increase in methane concentration over the historical period is reasonable compared to observation-based estimates despite the various specified and modelled sources and sinks that contribute to the time evolution of atmo- spheric methane burden. In Fig. 4a, the coefficient of correlation between observation-based (black line) and simulated (green and blue lines) $\left[\mathrm{CH}_{4}\right]$ is 0.99 and root mean square error (RMSE) is $35 \mathrm{ppb}$ (green line) and $41 \mathrm{ppb}$ (blue dashed line). The simulated values are somewhat overestimated from 1885 to 1980 and underestimated from 1980 to 2005 . The increase in observed methane concentration over the 1850 to 2008 period is $998 \mathrm{ppb}$, while the one-box model yields an increase of $1006 \mathrm{ppb}$ when initialized from observed 1850 methane concentration. The year 2008 concentration is calculated to be $1797 \mathrm{ppb}$ compared to the observation-based value of $1790 \mathrm{ppb}$.

An alternative approach to evaluate the modelled natural sinks and sources is to specify the rate of increase of atmospheric methane burden according to its observations and calculate the required atmospheric lifetime of methane (excluding the soil sink), given modelled natural sinks and sources, following Eq. (5) as discussed in Sect. 2.2.1. These results are shown in Fig. $4 \mathrm{~b}$, which compares the methane lifetimes required to achieve the observed increase in methane concentration over the historical period (black line) to within $\pm 3 \mathrm{ppb}$ (shaded area between grey lines) with observation-based estimate of atmospheric methane lifetime based on Prather et al. (2012) and the adjusted atmospheric methane lifetime from CMAM (both of which were shown earlier in Fig. 2). Figure $4 b$ shows that for the most part, the calculated atmospheric methane lifetime stays within the uncertainty of observation-based estimates. Moreover the temporal trend after 1900 in calculated atmospheric methane lifetime compares well to the trend in the atmospheric methane lifetime from the CMAM model. Both anthropogenic emissions and methane concentration during the early part of the 1850-2008 historical period are more uncertain than during the later part and thus the differences between simulated and observation-based estimates of atmospheric methane concentration (in Fig. 4a) and methane lifetimes (in Fig. 4b) for the period 1850-1900 are not unexpected.

While the results in Fig. 4a and b provide some confidence that the magnitude and temporal evolution of simulated global natural methane sources and sinks over the historical period are reasonable they, of course, do not allow the evaluation of all of the simulated natural fluxes individually.

We also evaluate the role of increase in wetland methane emissions over the historical period (as seen in Fig. 3) on the historical methane budget. Instead of using wetland methane emissions from the transient historical simulation in the onebox model of atmospheric methane we use wetland methane emissions from the equilibrium pre-industrial simulation in which 1901-1925 CRU-NCEP meteorological data are used repeatedly and $\mathrm{CO}_{2}$ is held constant at its pre-industrial level of $285 \mathrm{ppm}$. As a result wetland extent and methane emissions do not respond to changes in climate and increasing $\mathrm{CO}_{2}$, and do not increase over the historical period (as seen in Fig. 5a). Methane emissions from fire and soil uptake of 


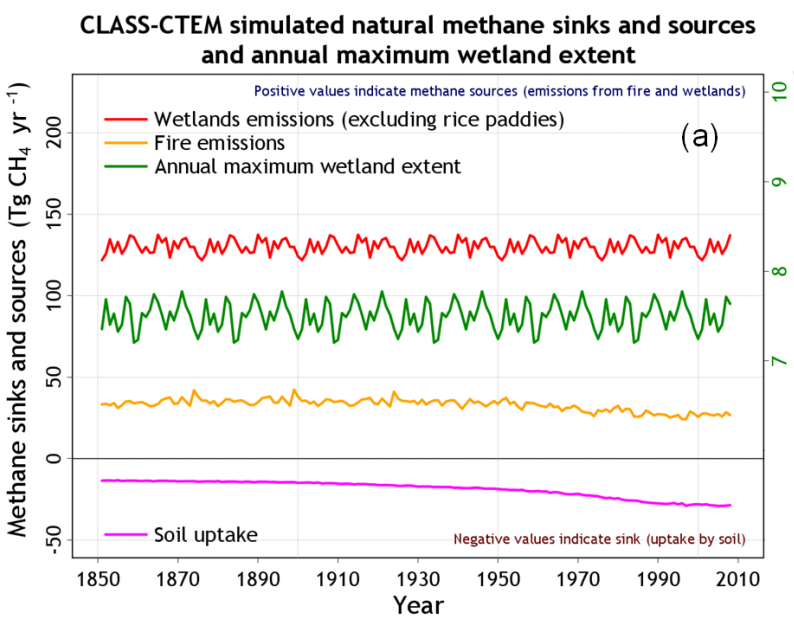

Atmospheric methane concentration (ppb)

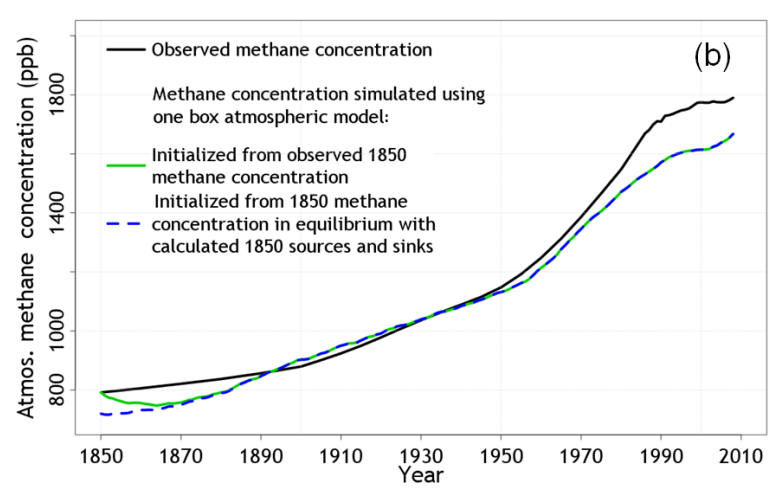

Figure 5. Time evolution of simulated natural methane fluxes (shown on the primary $y$ axis) and annual maximum wetland extent (shown on the secondary $y$ axis) by CLASS-CTEM for the 18512008 period for the case when wetland extent and methane emissions are not allowed to respond to changing climate and increase atmospheric $\mathrm{CO}_{2}$ over the historical period (a). Panel (b) shows the simulated methane concentration over the historical period, together with its observation-based values, when the natural fluxes shown in panel (a) are used within the framework of the one-box model of atmospheric methane.

methane still respond to changes in climate and increasing $\mathrm{CO}_{2}$. The result of using these wetland methane emissions (shown in Fig. 5a) in the framework of the one-box model of atmospheric methane is shown in Fig. 5b. In Fig. 5b, although $\left[\mathrm{CH}_{4}\right]$ increases overall over the historical period in response to increase in anthropogenic emissions, the result of wetland methane emissions not increasing over the historical period is that the simulated atmospheric methane concentration in year 2008 is calculated to be $1667 \mathrm{ppm}$, which is $130 \mathrm{ppb}$ lower than the 1797 ppb seen in Fig. 4a.

\subsection{Geographical distribution of wetland extent}

Figure 6 compares the zonally averaged maximum wetland fraction over land with observation-based estimates based on

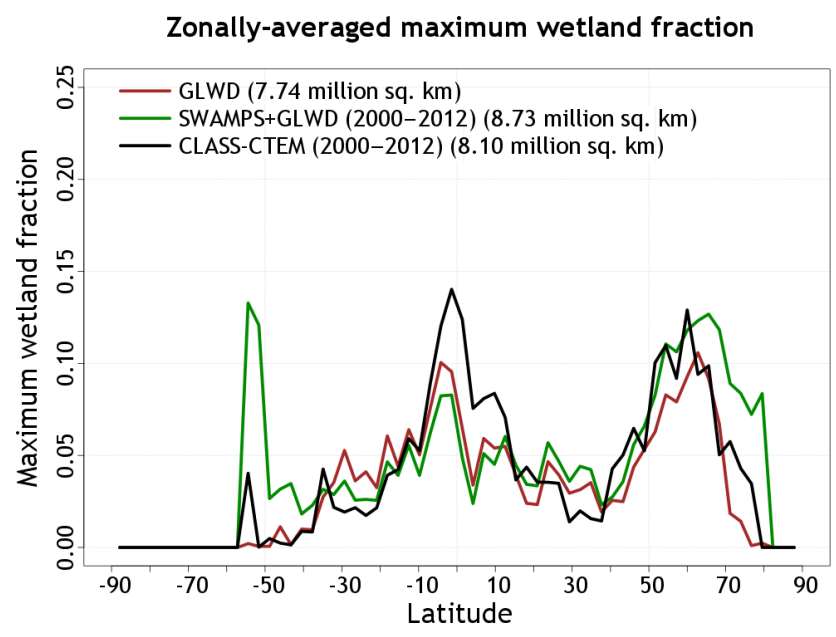

Figure 6. Comparison of simulated zonally averaged maximum wetland fraction over land with observation-based estimates based on the Global Lakes and Wetland (GLWD; Lehner and Döll, 2004) and a new product that is formed by merging remote sensing based observations of daily surface inundation from the Surface Water Microwave Product Series (SWAMPS; Schroeder et al., 2015) with the static inventory of wetland area from the GLWD as explained in Poulter et al. (2017).

the Global Lakes and Wetland (GLWD; Lehner and Döll, 2004) and the new product formed by merging remote sensing based observations of daily surface inundation from the Surface Water Microwave Product Series (SWAMPS; Schroeder et al., 2015) with the static inventory of wetland area from the GLWD from Poulter et al. (2017), as mentioned earlier in Sect. 2.1.3. Maximum wetland fraction from the model and SWAMPS + GLWD product is calculated as the maximum of 12 mean monthly values from the 13 years spanning the 2000-2012 period. Figure 6 shows that overall the model is able to capture the broad latitudinal distribution of wetlands with higher wetland fraction at northern highlatitudes and in the tropics. The model yields higher wetland fraction in the tropics than both observation-based estimates and this is due to higher wetland fraction simulated in the Amazonian region. The Amazonian region is densely forested and the SWAMPS product is unable to map wetlands beneath closed forest canopies. Biases also likely exist in the GLWD data set as parts of the Amazonian region are fairly remote. This is shown in Fig. 7 which compares the geographical distribution of simulated annual maximum wetland fraction with that from the GLWD and SWAMPS + GLWD products. The model successfully captures wetlands in the Hudson Bay lowlands, the West Siberian lowlands, the Pantanal and the region bordering Argentina, Paraguay and Uruguay in South America, Indonesia, and the low lying region around Bangladesh. In terms of differences from these observation-based data sets the model most notably overestimates wetland extent in Europe. One possible reason for this is that wetlands in Europe have been drained for agricul- 
Table 2. Comparison of CLASS-CTEM simulated annual methane emissions and annual maximum wetland extent for the West Siberia lowlands (WSL) region with models participating in the WETCHIMP-WSL intercomparison and observation- and inversion-based estimates as discussed in Sect. 3.5. Numbers shown are mean \pm standard error from Bohn et al. (2015) for models participating in the WETCHIMPWSL intercomparison. Standard error is not available for all inversions. All values are reported as average for the period 1993-2004 unless otherwise noted.

\begin{tabular}{lr}
\hline \multicolumn{2}{c}{ WSL annual maximum wetland extent $\left(\right.$ million $\left.\mathrm{km}^{2}\right)$} \\
\hline Model mean from participating models in the WETCHIMP-WSL intercomparison & $0.70 \pm 0.15$ \\
CLASS-CTEM (this study) & 0.53 \\
GIEMS inundation data set & 0.21 \\
SWAMPS inundation data set & 0.15 \\
SWAMPS and GCP product (for period 2002-2012) & 0.55 \\
Peregon et al. (2009) & 0.68 \\
\hline \multicolumn{2}{c}{ WSL annual wetland emissions $\left(\mathrm{Tg} \mathrm{CH}_{4} \mathrm{yr}^{-1}\right)$} \\
\hline Model mean from participating models in the WETCHIMP-WSL intercomparison \\
CLASS-CTEM (this study) & $5.34 \pm 0.54$ \\
Bousquet 2011 K & 7.76 \\
Bousquet 2011 R & 7.06 \\
Kim 2011 (for year 2005) & 7.13 \\
Winderlich (2012) (for year 2009) & $3.08 \pm 1.40$ \\
\hline
\end{tabular}

ture and our wetland parameterization does not take this into account. About two-thirds of the European wetlands that existed 100 years ago have been lost (European Commission, 1995) leading to a substantial decrease in the number and size of large bogs and marshes, and small or shallow lakes.

\subsection{Geographical distribution of simulated natural fluxes}

Figure 8 shows the geographical distribution of methane emissions from dynamic wetlands (panel a) and fire (panel b) and the soil uptake of methane (panel c) simulated by the CLASS-CTEM model. The figures also show the global total of these fluxes averaged over the 2000-2008 period for later comparison with estimates from Saunois et al. (2016). Methane emissions from wetlands (168.9 $\mathrm{Tg} \mathrm{CH}_{4} \mathrm{yr}^{-1}$ ) are the largest of natural fluxes, as is well known, while emissions from fire $\left(26.8 \mathrm{Tg} \mathrm{CH}_{4} \mathrm{yr}^{-1}\right)$ and methane uptake by soil (28.7 $\mathrm{Tg} \mathrm{CH}_{4} \mathrm{yr}^{-1}$ ) are an order of magnitude lower. As expected, the geographical distribution of methane emissions from wetlands (Fig. 8a) corresponds well to the geographical distribution of wetlands themselves (Fig. 7a) although per unit wetland area methane emissions are higher in tropics and milder temperate regions than in high-latitude regions. This is because warmer temperatures and a longer growing season in the tropical and milder temperate regions imply that wetlands can emit more methane per unit wetland area and for a longer period of time than the colder high-latitude regions with a shorter growing season. In Fig. 8b the geographical distribution of methane fire emissions shows higher values in seasonally dry tropical regions and order of magnitudes lower values in mid-high latitude regions. These results are consistent with area burned (not shown), which shows a sim- ilar pattern (Arora and Melton, 2018). Finally, the geographical distribution of methane uptake by soils in Fig. 8c shows higher methane uptake by soils in parts of arid regions (including the Sahara and the Australian outback) where soil moisture does not get too dry (so as to not excessively limit soil microbial activity) but otherwise has fairly uniform uptake in the tropics and lower values in mid-high latitude regions where lower temperatures and higher soil moisture limit methane uptake by soils.

\subsection{Regional evaluation over West Siberian lowlands}

While evaluation of simulated global wetland extent and wetland methane emissions, and their geographical distribution, provides confidence in model results, we further evaluate the model at a regional scale over the West Siberia lowlands. The model results are sampled for the region lying between 50 to $75^{\circ} \mathrm{N}$ and 60 to $95^{\circ} \mathrm{E}$ for comparison with observation- and inversion-based estimates (mentioned earlier in Sect. 2.1.3). Figure 9a compares CLASS-CTEM simulated wetland extent with those from models participating in the WETCHIMP-WSL intercomparison, and the GIEMS, SWAMPS and merged SWAMPS, and GLWD products mentioned in Sect. 2.1.3. Table 2 compares the simulated annual maximum wetland extent with models participating in the WETCHIMP-WSL intercomparison and these observationbased products. All values are reported as average for the period 1993-2004 except for the merged SWAMPS and GLWD product whose average is for the 2002-2012 period, and the Peregon et al. (2009) estimate that is based on wetland typology map from a 1977 publication and a more recent satellite land cover product. CLASS-CTEM simulated monthly wetland extent in Fig. 9a compares best with the merged 


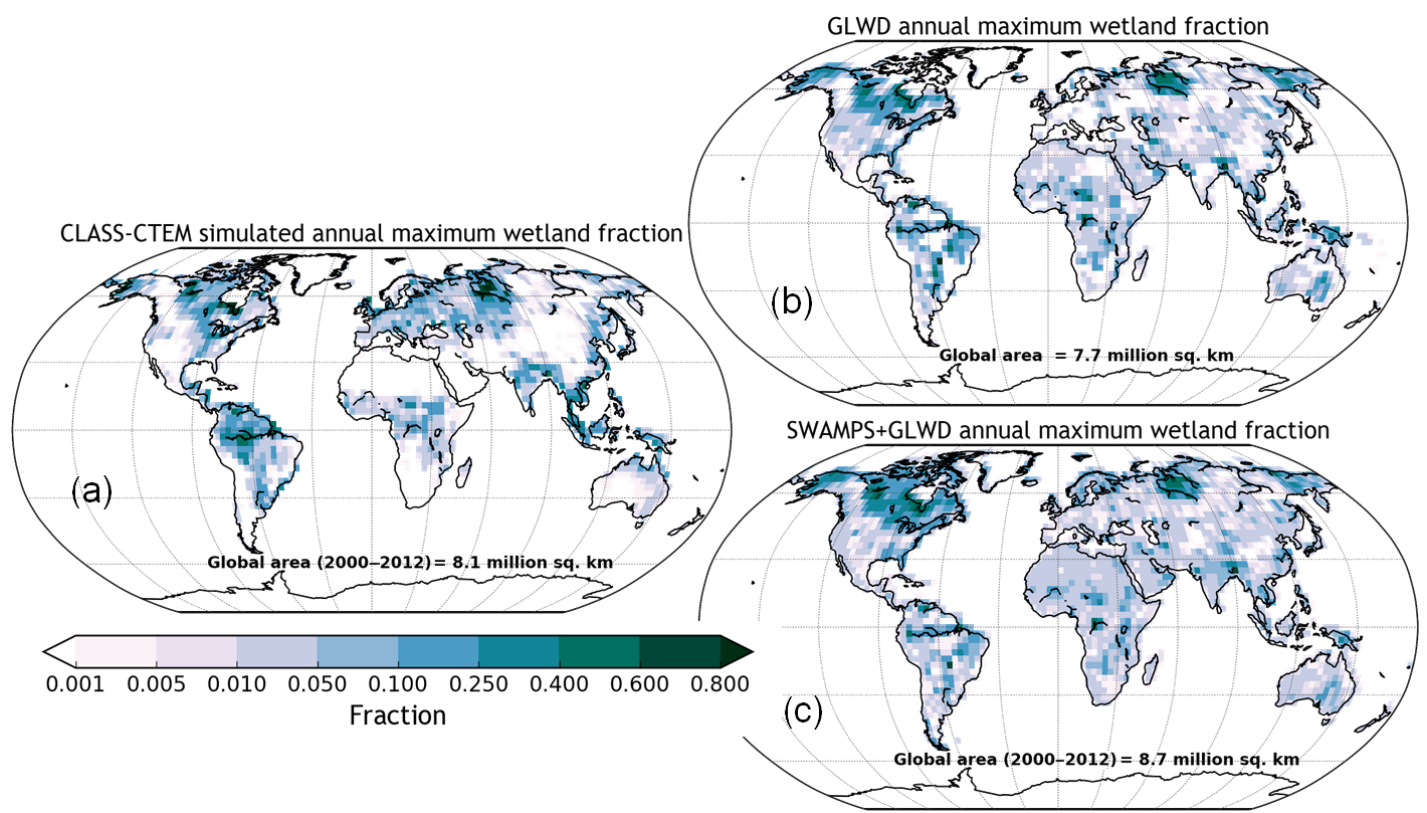

Figure 7. Comparison of geographical distribution simulated annual maximum wetland fraction with observation-based estimates based on the Global Lakes and Wetland (GLWD; Lehner and Döll, 2004) and a new product that is formed by merging remote sensing based observations of daily surface inundation from the Surface Water Microwave Product Series (SWAMPS; Schroeder et al., 2015) with the static inventory of wetland area from the GLWD as explained in Poulter et al. (2017).

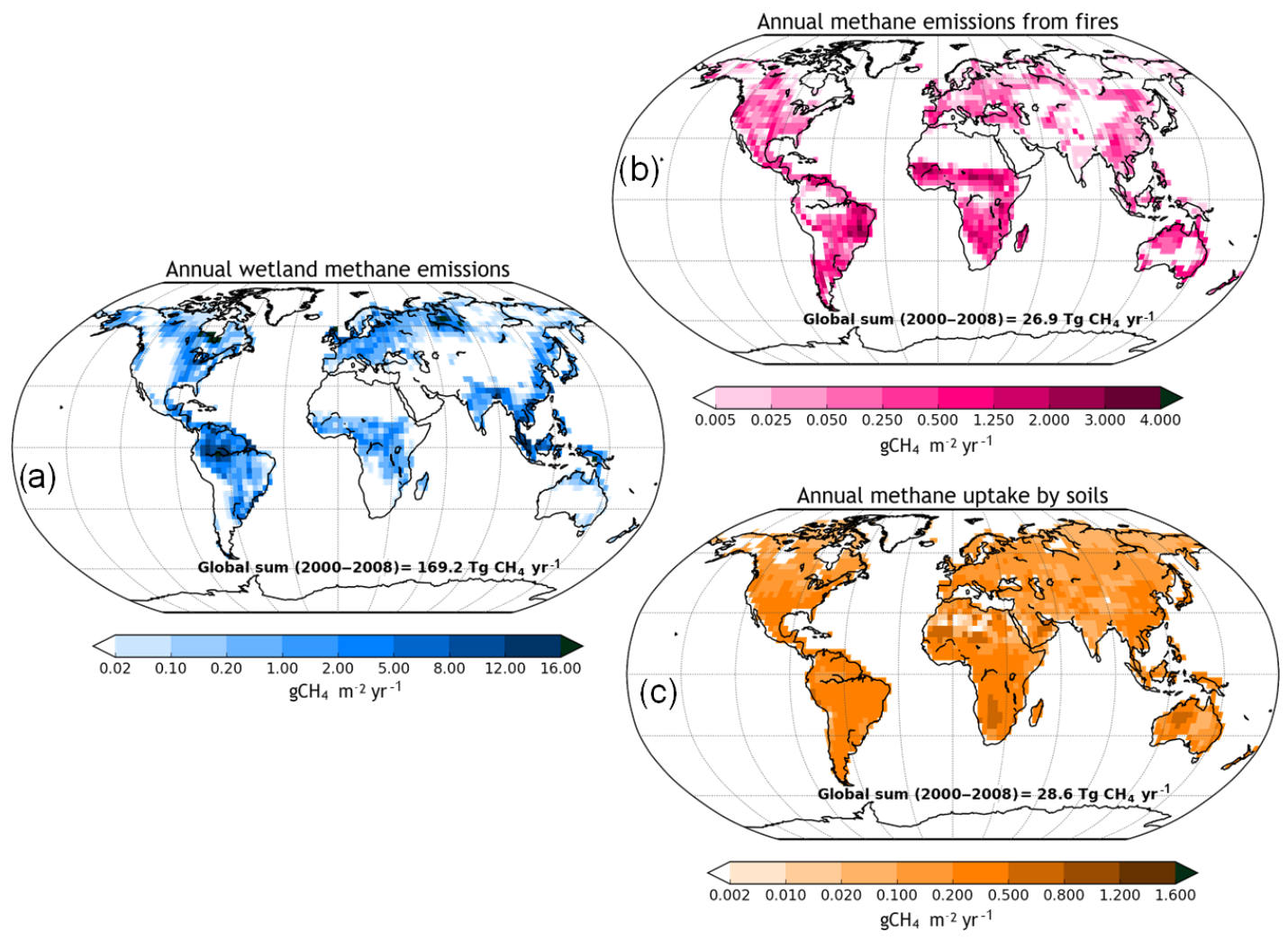

Figure 8. Geographical distribution of annual emissions from wetlands (a) and fire (b), and the soil sink (c) simulated by the CLASS-CTEM model. The data are averaged over the 2000-2009 period. 

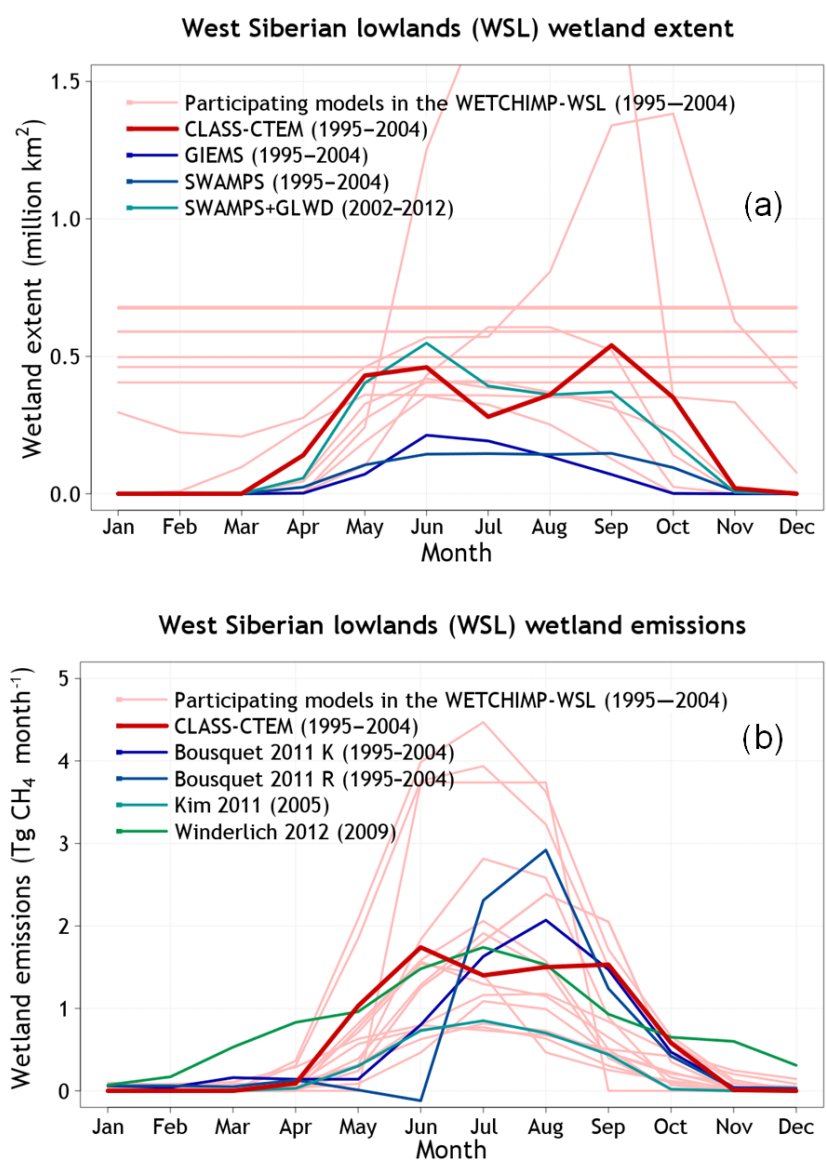

Figure 9. Comparison of CLASS-CTEM simulated wetland extent (a) and wetland methane emissions (b) over the West Siberian lowlands (WSL) region with those from models participating in the WETCHIMP-WSL intercomparison and observation- and inversion-based estimates as discussed in Sect. 3.5.

SWAMPS and GLWD product, while both the satellite-based inundation products by themselves (SWAMPS and GIEMS) show much lower values. Satellite-based products that remotely sense inundated areas can only do so when water table is above the ground and thus wetland areas inferred from these products are expected to be lower in magnitude than products that also take into account land cover, as is the case for the merged SWAMPS and GLWD product.

In Table 2, the annual maximum wetland extent is quite similar for the merged SWAMPS and GLWD product $\left(0.55\right.$ million $\left.\mathrm{km}^{2}\right)$ and CLASS-CTEM simulated values $\left(0.53\right.$ million $\left.\mathrm{km}^{2}\right)$ but the maximum occurs in different months. In Fig. 9b, for the merged SWAMPS and GLWD product the maximum wetland extent occurs in June while CLASS-CTEM simulated values show peak both in June and September. The participating models from the WETCHIMP-WSL intercomparison show a range of values for the monthly wetland extent in the WSL region (Fig. 9a). Models range from those which specify constant values with no seasonality for the wetland ex- tent to models that dynamically model wetland extent two of which show maximum wetland extent of greater than 1 million $\mathrm{km}^{2}$. The average annual maximum wetland extent across the participating models in the WETCHIMP-WSL is $0.70 \pm 0.15$ million $\mathrm{km}^{2}$ (mean \pm standard error). Finally, the Peregon et al. (2009) estimate is 0.68 million $\mathrm{km}^{2}$, which is somewhat higher than the CLASS-CTEM simulated value $\left(0.53\right.$ million $\left.\mathrm{km}^{2}\right)$ and the merged SWAMPS and GLWD product $\left(0.55\right.$ million $\left.\mathrm{km}^{2}\right)$.

Figure 9b compares CLASS-CTEM simulated monthly wetland methane emissions with those from models participating in the WETCHIMP-WSL intercomparison and four inversion-based estimates mentioned in Sect. 2.1.3. The two Bousquet et al. (2011) inversions shown in Fig. 9b correspond to ones using the reference Matthews and Fung (1987) emissions inventory (Bousquet $2001 \mathrm{R}$ ) and the emissions inventory based on Kaplan (2002) (Bousquet 2001 K). All values are reported as average for the period 1993-2004 except for the Kim et al. (2011) inversion which reports fluxes for year 2005 and the Winderlich (2012) inversion which corresponds to year 2009.

Table 2 compares the simulated annual wetland methane emissions from CLASS-CTEM with those from models participating in the WETCHIMP-WSL intercomparison and the four inversion-based estimates. In Table 2, the inversionbased annual wetland methane emissions vary from 3.08 to $9.80 \mathrm{TgCH}_{4} \mathrm{yr}^{-1}$. The highest annual emissions in the Winderlich (2012) inversion are due to higher emissions in the shoulder months of spring and fall compared to other inversions but also non-zero emissions during winter months (December to February) as seen in Fig. 9b. The CLASS-CTEM model calculates annual wetland methane emissions of $7.76 \mathrm{Tg} \mathrm{CH}_{4} \mathrm{yr}^{-1}$ and the average for models participating in the WETCHIMP-WSL intercomparison is $5.34 \pm 0.54 \mathrm{Tg} \mathrm{CH}_{4} \mathrm{yr}^{-1}$ (mean \pm standard error). Of all the models and inversions only the Winderlich (2012) inversion shows substantial methane emissions for the November to April period. In CLASS-CTEM as the liquid soil moisture in the top soil layer freezes wetland extent contracts to zero (Fig. 9a) and methane emissions are shut off during the winter months. Bohn et al. (2015) note that Winderlich (2012) inversion-based estimates may have been influenced by emissions from fossil fuel extraction and biomass burning, although the seasonality of Winderlich (2012) fluxes, with nonzero emissions even in winter, is plausible. Based on yearround eddy flux measurements of methane emissions from Alaskan Arctic tundra sites, Zona et al. (2016) find that cold season (September to May) emissions account for $\geq 50 \%$ of the annual methane flux, with the highest emissions from non-inundated upland tundra. They find a major fraction of cold season emissions occur during the "zero curtain" period, when subsurface soil temperatures are near $0^{\circ} \mathrm{C}$. Langer et al. (2015) report winter emissions from tundra ponds in Siberia as they are freezing during early winter. They analyzed concentrations of methane in bubbles (trapped in the 
Table 3. Comparison of the components of the present day methane budget based on this study with those from Saunois et al. (2016) (based on synthesis of published studies). The values used in this study are averaged for the period 2000-2008 (as the last year of the version of EDGAR emissions used is 2008) while Saunois et al. (2016) values correspond to the 2000-2009 period.

\begin{tabular}{lrrl}
\hline & $\begin{array}{r}\text { Saunois et al. (2016) } \\
\text { estimates based on } \\
\text { top-down approaches }\end{array}$ & Values & Method \\
\hline Natural sources & $234[194-292]$ & 199 & \\
\hline Natural wetlands & $166[125-204]$ & 169 & $\begin{array}{l}\text { CLASS-CTEM simulated } \\
\text { Other natural sources }\end{array}$ \\
(termites, geological, fresh water etc.) & $68[21-130]$ & 30 & $\begin{array}{l}\text { Specified as a constant } \\
\text { over the historical period }\end{array}$ \\
\hline Anthropogenic sources & $319[255-357]$ & 344 & \\
\hline Agriculture and waste & $183[112-241]$ & 200 & EDGAR \\
Fossil fuels & $101[77-126]$ & 117 & $\begin{array}{l}\text { EDGAR } \\
\text { CLASS-CTEM simulated }\end{array}$ \\
Biomass and biofuel burning & $35[16-53]$ & 27 & CLSS \\
\hline Sum of all sources & $552[535-566]$ & 543 & \\
\hline Sum of all sinks & 546 & 538 & \\
\hline Atmospheric sink & 514 & 509 & $\begin{array}{l}\text { Based on specified bias-corrected } \\
\text { atmospheric CH }\end{array}$ lifetimes from CMAM \\
Soil sink & $32[27-38]$ & 29 & CLASS-CTEM simulated \\
\hline
\end{tabular}

lake ice), which were higher at depths than at the ice surface. So it is entirely plausible that methane emissions occur during transition to winter months, which models fail to simulate and most inversions fail to capture.

\subsection{Evaluation of present-day global methane budget}

Our final evaluation of simulated global methane budget is against estimates compiled by Saunois et al. (2016) who synthesize several recent studies to summarize the present-day global methane budget. Our global methane budget is based on simulated and specified fluxes and the use of one-box model of atmospheric methane. We exclusively evaluate our simulated global methane budget against the top-down approaches presented in Saunois et al. (2016) as estimates from bottom-up approaches are known to yield higher total emissions than those based on top-down approaches as mentioned earlier in the Introduction. The global methane budget based on top-down approaches which are constrained by the atmospheric $\mathrm{CH}_{4}$ burden and its loss in the atmosphere is considered more reliable than that based on the bottom-up approaches. These comparisons are shown in Table 3. The natural and anthropogenic sources are divided into their broad categories and so are the sinks which are divided into atmospheric and soil sinks. The Saunois et al. (2016) estimates are reported for the period 2000-2009, while the CLASSCTEM values correspond to the 2000-2008 period since the EDGAR anthropogenic emissions were available only until 2008 at the time of this study and thus the one-box model of atmospheric methane is also run up until 2008. For clarity, Table 3 also identifies which fluxes are modelled by CLASS-
CTEM, which are specified and which are based on atmospheric methane lifetimes.

In Table 3 the total emissions from natural sources in our framework are $199 \mathrm{Tg} \mathrm{CH}_{4} \mathrm{yr}^{-1}$ which are in the lower part of the range of 194-292 $\mathrm{Tg} \mathrm{CH}_{4} \mathrm{yr}^{-1}$ compiled by Saunois et al. (2016). This is due to lower specified emissions from nonwetland sources. While our modelled emissions from wetlands of $169 \mathrm{Tg} \mathrm{CH}_{4} \mathrm{yr}^{-1}$ compare well with the Saunois et al. (2016) central estimate of $166 \mathrm{Tg} \mathrm{CH}_{4} \mathrm{yr}^{-1}$, our specified emissions from other natural sources (including termites, geological sources and fresh water bodies) of $25 \mathrm{Tg} \mathrm{CH}_{4} \mathrm{yr}^{-1}$ are near the low end of their range (21-130 $\left.\mathrm{Tg} \mathrm{CH}_{4} \mathrm{yr}^{-1}\right)$. In contrast, our anthropogenic emissions of $344 \mathrm{Tg} \mathrm{CH}_{4} \mathrm{yr}^{-1}$ (which include emissions from fire for consistency with Saunois et al., 2016) are higher than Saunois et al. (2016) central estimate of $319 \mathrm{Tg} \mathrm{CH}_{4} \mathrm{yr}^{-1}$ and towards the higher end of their range (255-357 $\left.\mathrm{Tg} \mathrm{CH}_{4} \mathrm{yr}^{-1}\right)$. This is due to the use of EDGAR emissions which as Saunois et al. (2016) note are towards the higher end of all data sets of anthropogenic emissions. Our modelled fire emissions of $27 \mathrm{Tg} \mathrm{CH}_{4} \mathrm{yr}^{-1}$ are lower than Saunois et al. (2016) central estimate of $35 \mathrm{Tg} \mathrm{CH}_{4} \mathrm{yr}^{-1}$. One reason for this is that while we include natural and anthropogenic fires in our framework we do not account for biofuel burning. Overall, our emissions from natural sources are $35 \mathrm{Tg} \mathrm{CH}_{4} \mathrm{yr}^{-1}$ lower, and emissions from anthropogenic sources are $25 \mathrm{Tg} \mathrm{CH}_{4} \mathrm{yr}^{-1}$ higher, than the Saunois et al. (2016) central estimates. As a result, the sum of natural and anthropogenic emissions (543 $\left.\mathrm{Tg} \mathrm{CH}_{4} \mathrm{yr}^{-1}\right)$ in our framework is $9 \mathrm{TgCH}_{4} \mathrm{yr}^{-1}$ lower than Saunois et al. (2016) central estimate $\left(552 \mathrm{Tg} \mathrm{CH}_{4} \mathrm{yr}^{-1}\right)$. 
The total sink strength is calculated to be $538 \mathrm{Tg} \mathrm{CH}_{4} \mathrm{yr}^{-1}$ in our framework which compares well with the Saunois et al. (2016) estimate of $546 \mathrm{Tg} \mathrm{CH}_{4} \mathrm{yr}^{-1}$. Saunois et al. (2016) do not provide uncertainty ranges for the atmospheric and total sink. The modelled atmospheric $\left(509 \mathrm{Tg} \mathrm{CH}_{4} \mathrm{yr}^{-1}\right)$ and soil $\left(29 \mathrm{Tg} \mathrm{CH}_{4} \mathrm{yr}^{-1}\right)$ sinks in Table 3 also compare well with Saunois et al. (2016) estimates of 514 and $32 \mathrm{Tg} \mathrm{CH}_{4} \mathrm{yr}^{-1}$, respectively.

\section{Discussion and conclusions}

The offline evaluation of natural methane fluxes simulated by the CLASS-CTEM modelling framework presented here is the first step in making atmospheric methane concentration a prognostic variable in the family of Canadian earth system models. The evaluation is based on comparison of presentday fluxes with existing observation- and model-based estimates compiled by Saunois et al. (2016) but also the historical evolution of atmospheric methane burden and methane's lifetime simulated using a one-box model of atmospheric methane. While our simulated and specified present-day global methane budget components lie within the uncertainty range for top-down estimates from Saunois et al. (2016) this also implies that methane emissions from individual sectors for the present-day budget can be increased or decreased within their uncertainty ranges as long as the total emissions stay the same. However, the time evolution of the atmospheric methane burden over the historical period provides additional constraints than the present-day methane budget. For example, our specified methane emissions of $25 \mathrm{Tg} \mathrm{CH}_{4} \mathrm{yr}^{-1}$ from other nature sources $\left(E_{\mathrm{o}}\right)$ (including termites, geological sources, wild animals, and freshwater) are lower than Saunois et al. (2016) central estimate of $68 \mathrm{Tg} \mathrm{CH}_{4} \mathrm{yr}^{-1}$, although still within their uncertainty range (21-130 $\left.\mathrm{Tg} \mathrm{CH}_{4} \mathrm{yr}^{-1}\right)$. In the absence of any information about its time evolution we have assumed that $E_{\mathrm{o}}$ remains constant over the historical period. This is a plausible assumption as we do not expect emissions from termites, geological sources, wild animals, and freshwater to show a large response to changing environmental conditions over the historical period. Certainly, not as large as we saw for wetland emissions which increased by $40 \mathrm{Tg} \mathrm{CH}_{4} \mathrm{yr}^{-1}$ over the 1850-2008 period (Fig. 3). However, when we use a constant $E_{\mathrm{o}}$ of $68 \mathrm{TgCH}_{4} \mathrm{yr}^{-1}$ in our framework we obtain higher than observed methane concentration throughout the historical period and the year 2008 value is $1953 \mathrm{ppb}$ compared to $1797 \mathrm{ppb}$ that we obtain in Fig. 4a (observed methane concentration for 2008 is $1790 \mathrm{ppb}$ ). This is shown in Fig. 10. Part of the reason for this may be that present-day EDGAR emissions are higher than other estimates as Saunois et al. (2016) note and that's why we had to choose a lower $E_{\mathrm{o}}$. However, the global harmonized and RCP anthropogenic emissions are fairly similar up until 1990 (see Fig. 1a) and thus had we use RCP based emissions (up until year 2000) we still would have obtained higher than observed atmo-

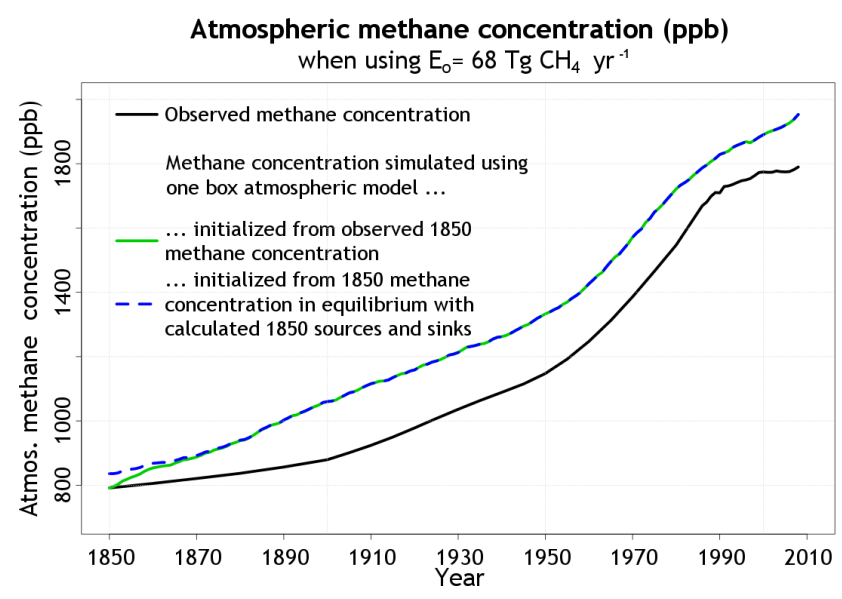

Figure 10. Simulated methane concentration over the historical period, together with its observation-based values, when other non-wetland natural methane emissions $\left(E_{0}\right)$ are specified at $68 \mathrm{Tg} \mathrm{CH}_{4} \mathrm{yr}^{-1}$ over the historical period.

spheric methane concentrations throughout the historical period when using $E_{\mathrm{o}}$ of $68 \mathrm{Tg} \mathrm{CH}_{4} \mathrm{yr}^{-1}$. Our framework cannot accommodate $E_{\mathrm{o}}$ larger than about $25-30 \mathrm{Tg} \mathrm{CH}_{4} \mathrm{yr}^{-1}$ without overestimating atmospheric methane concentrations throughout the historical period.

The second constraint provided by the time evolution of the atmospheric methane burden over the historical period is that related to wetland methane emissions. As seen in Sect. 3.2, in the absence of the simulated increase in wetland methane emissions from about 130 to $170 \mathrm{Tg} \mathrm{CH}_{4} \mathrm{yr}^{-1}$ from 1850 s to the present day the simulated year 2008 atmospheric methane concentration is about $100 \mathrm{ppb}$ lower than observed (as seen in Fig. 5). Assuming our RCP and EDGAR based harmonized anthropogenic emissions and their increase over the historical period is reasonably realistic, this indicates that it is very likely that wetland methane emissions have indeed increased over the historical period in response to changes in climate and increased atmospheric $\mathrm{CO}_{2}$ concentration. The results in Sect. 3.1 showed that this increase of $30 \%$ in wetland methane emissions in driven more by an increase in methane emissions per unit area than the increase in maximum wetland extent, which increased by about $8 \%$ over the historical period. The implication of this is that wetland methane emissions will likely keep increasing in the future in response to the increasing atmospheric concentration of $\mathrm{CO}_{2}$ driven by higher heterotrophic respiration.

The evaluation of simulated wetland extent against the GLWD and the merged SWAMPS and GLWD product provides confidence that the model is broadly able to reproduce the geographical distribution of wetlands although, of course, some limitations remain. Over the WSL region the simulated estimates of wetland extent and wetland methane emissions are also broadly consistent with observation-based estimates. 
The version of the model used here treats its land mask as binary so each grid cell is either land or water. While the model is capable of representing inland lakes using a separate tile (and simulate the resulting impact on energy and water fluxes) this functionality was not used in this study. In addition, representation of inland lakes requires modelling methane emissions from their anoxic sediment (Bastviken et al., 2004) and care needs to be taken to avoid double counting the wetland extent of inland lakes (Thornton Brett et al., 2016).

We have not evaluated the model's wetland methane emissions at the site level against observations. Wetland methane emissions are known to be spatially highly heterogeneous and temporally intermittent (e.g. Godwin et al., 2013) and CLASS-CTEM does not represent physical processes that govern methane emissions at small spatial and temporal scales. Instead the model is designed for operation at large spatial scales $(>100 \mathrm{~km})$ and implementation within an Earth system model and as such only temperature, soil moisture, and substrate availability (through heterotrophic respiration) are taken into account. Water table depth, ebullition, transport through vascular plants, and PFTs specific to wetlands are not considered in our modelling framework. The corollary of this is that our model cannot be expected to reproduce wetland methane emissions at a point scale where site specific processes and conditions including water depth, ebullition, and wetland specific PFTs become more important. Similar approaches are followed by several large scale models including a recent attempt by Bloom et al. (2017) who derive wetland methane emissions using heterotrophic respiration from eight terrestrial ecosystem models.

We have also not evaluated parameter and forcing uncertainties in relation to simulated methane emissions. However, several aspects of the CLASS-CTEM model have been evaluated before against observations including photosynthesis, autotrophic and heterotrophic respiration, allocation of carbon from leaves to stem and root components, dynamic leaf phenology, fire, and land use change. These aspects of the model have been evaluated at point (Arora and Boer, 2005a; Melton et al., 2015), regional (Peng et al., 2014; Garnaud et al., 2015; Arora et al., 2016) and global (Arora and Boer, 2010; Melton and Arora, 2014, 2016) scales. In regards to processes relevant to methane emissions from wetlands (which, of course, is the largest natural source) heterotrophic respiration and wetland extent are the most important. Uncertainties in these two quantities will propagate to calculated methane emissions from wetlands. The majority of in- crease in wetland methane emissions over the historical period comes from an increase in heterotrophic respiratory flux due to increase in gross and net primary productivities in response to increase in atmospheric $\mathrm{CO}_{2}$ concentration. The rate of increase of simulated gross primary productivity is adjusted in CLASS-CTEM to obtain realistic land carbon sink from 1960 onwards (Le Quéré et al., 2018) but also to obtain a realistic amplitude of the annual $\mathrm{CO}_{2}$ cycle in a fully coupled Earth system model simulation (Arora and Scinocca, 2016). The response of model's heterotrophic respiration to soil moisture is expressed as a function of soil matric potential as mentioned earlier in Sect. 2.1.1. This response is based on Griffin (1981) who suggests that the microbial activity is optimal at an absolute soil matric potential of $0.05 \mathrm{MPa}$ and decreases as the soil becomes waterlogged near $0.00 \mathrm{MPa}$ or too dry near $1.5 \mathrm{MPa}$. This parameterization has been evaluated indirectly at seasonally dry locations in the Amazonia (Melton et al., 2015).

Our next step to evaluate natural methane fluxes from CLASS-CTEM is to use these fluxes in an atmospheric transport model to simulate and compare methane concentrations at selected stations to assess seasonality of simulated wetland methane emissions at large spatial scales in a somewhat more direct manner. In addition, CLASS-CTEM simulated natural fluxes can be used as a prior in a methane inversion-based system, together with anthropogenic methane emissions, to calculate optimized posterior fluxes to which the prior fluxes can be compared. Although atmospheric inversions-based systems have their own limitations (Houweling et al., 2017), the objective is to evaluate CLASS-CTEM simulated natural methane fluxes using a range of available methodologies.

Overall the results presented here suggest that the natural fluxes of methane between the atmosphere and the land, and the geographical distribution of wetland extent, simulated by the CLASS-CTEM modelling framework are sufficiently realistic to use the model to study the changes in natural methane fluxes due to changes in environmental conditions.

Code and data availability. The data used in this study can be obtained from the first author (vivek.arora@canada.ca). The model code is available from https://gitlab.com/jormelton/classctem (GitLab, 2018) 


\section{Appendix A: Calculation of wetland extent}

The distribution of wetlands is based on a simple formulation, which takes into account the topography in a grid cell and its simulated grid-averaged soil moisture content similar to Kaplan (2002). The ETOPO1 digital elevation data (Amante and Eakins, 2009) are used to calculate slopes at $1 \operatorname{arcmin}\left(1 / 60^{\circ}\right)$ resolution. Each 1 arcmin grid cell is assigned a slope that is the average of eight slopes based on its elevation and the elevation of its eight surrounding grid cells. The objective is to find what fraction of a grid cell, at some given resolution, has slopes flatter than a given slope threshold. Figure A1 displays the fraction of each $0.5^{\circ}$ grid cell with slopes less than the threshold of 0.002 (i.e. $0.2 \%$ slope) calculated using 1 arcmin slopes, hereafter referred to as the "flat" fraction of a grid cell $\left(f_{\mathrm{s}}\right)$. The flat fraction of grid cell is also shown at the current operational $2.81^{\circ}$ resolution of CanESM4.2, which is the spatial resolution we have used in this study. Figure 1 shows that the approach is able to identify the flat regions of the world including the West Siberian and Hudson Bay lowlands, parts of northern Africa and in South America the Pantanal and the region bordering Argentina, Paraguay, and Uruguay.

The flat fraction is the maximum fraction of a grid cell that can potentially become a wetland, if soils are sufficiently wet, and thus a source of $\mathrm{CH}_{4}$ emissions. As the grid-averaged simulated soil wetness $(w)$ of the top soil layer increases above a given lower threshold ( $w_{\text {low }}$ ) in a grid cell, its wetland fraction $\left(f_{\mathrm{w}}\right)$ is assumed to increase linearly until some specified higher soil wetness threshold $\left(w_{\text {high }}\right)$ up to a maximum value equal to the flat fraction $\left(f_{\mathrm{s}}\right)$ in a grid cell.

$f_{\mathrm{w}}=\max \left(0, \min \left(f_{\mathrm{s}},\left(\frac{w-w_{\text {low }}}{w_{\text {high }}-w_{\text {low }}}\right) f_{\mathrm{s}}\right)\right)$

Soil wetness $\left(w=\frac{\theta_{1}}{\theta_{\mathrm{p}}}\right)$ itself is defined as the ratio of volumetric liquid soil moisture content $\left(\theta_{1}\right)$ to the soil porosity $\left(\theta_{\mathrm{p}}\right)$ for the top soil layer. The remaining fraction of the grid cell $\left(1-f_{\mathrm{W}}\right)$ is considered as the upland fraction. As simulated liquid soil moisture in the top soil layer responds to changes in environmental conditions the dynamic wetlands expand and contract. The upper and lower soil wetness thresholds are summarized in Table A1 and adapted to yield realistic geographical and latitudinal distribution of wetland extent compared to observation-based estimates.

Table A1. The upper and lower soil wetness thresholds for three latitudinal bands used in Eq. (1) to determine fractional wetland coverage in a given grid cell.

\begin{tabular}{lrrr}
\hline & \multicolumn{2}{c}{ Latitudinal band } \\
& 40 to $90^{\circ} \mathrm{N}$ & $35^{\circ} \mathrm{S}$ to $40^{\circ} \mathrm{N}$ & 90 to $35^{\circ} \mathrm{S}$ \\
\hline$w_{\text {low }}$ & 0.45 & 0.55 & 0.70 \\
$w_{\text {high }}$ & 0.90 & 0.99 & 0.99 \\
\hline
\end{tabular}

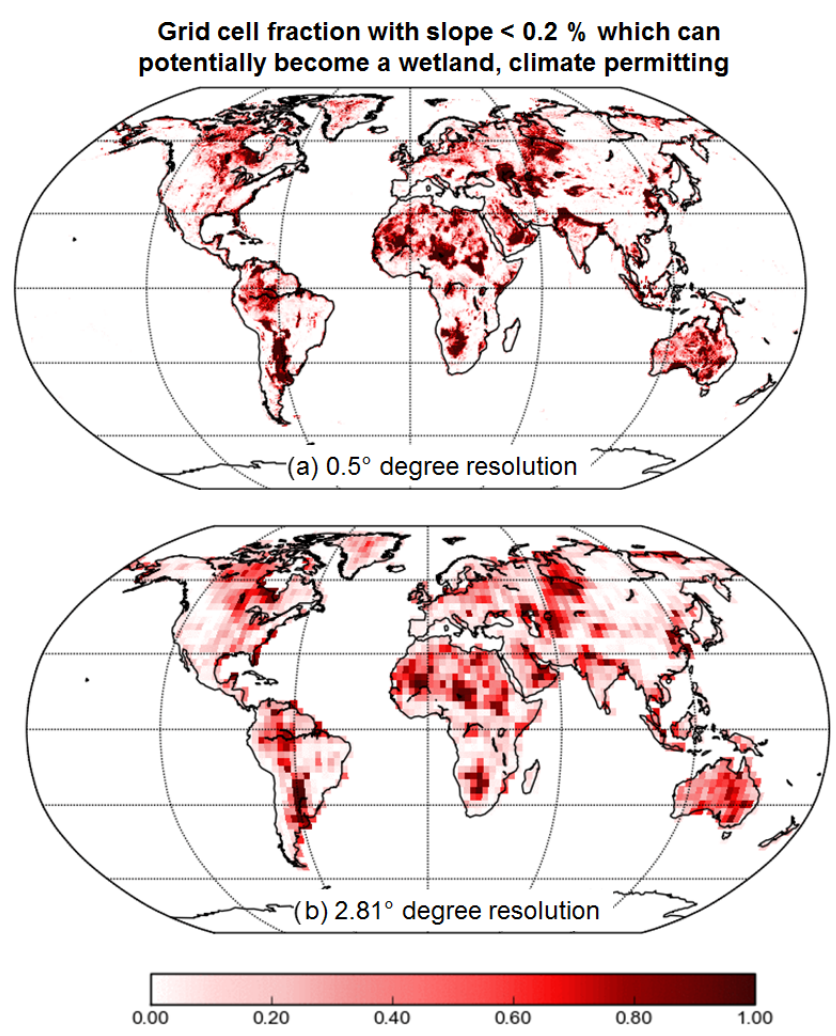

Figure A1. Fraction of grid cell with slopes less than the threshold of 0.002 (i.e. $0.2 \%$ slope) at (a) $0.5^{\circ}$ and (b) $2.81^{\circ}$ spatial resolutions, respectively. 
Appendix B: Driving data
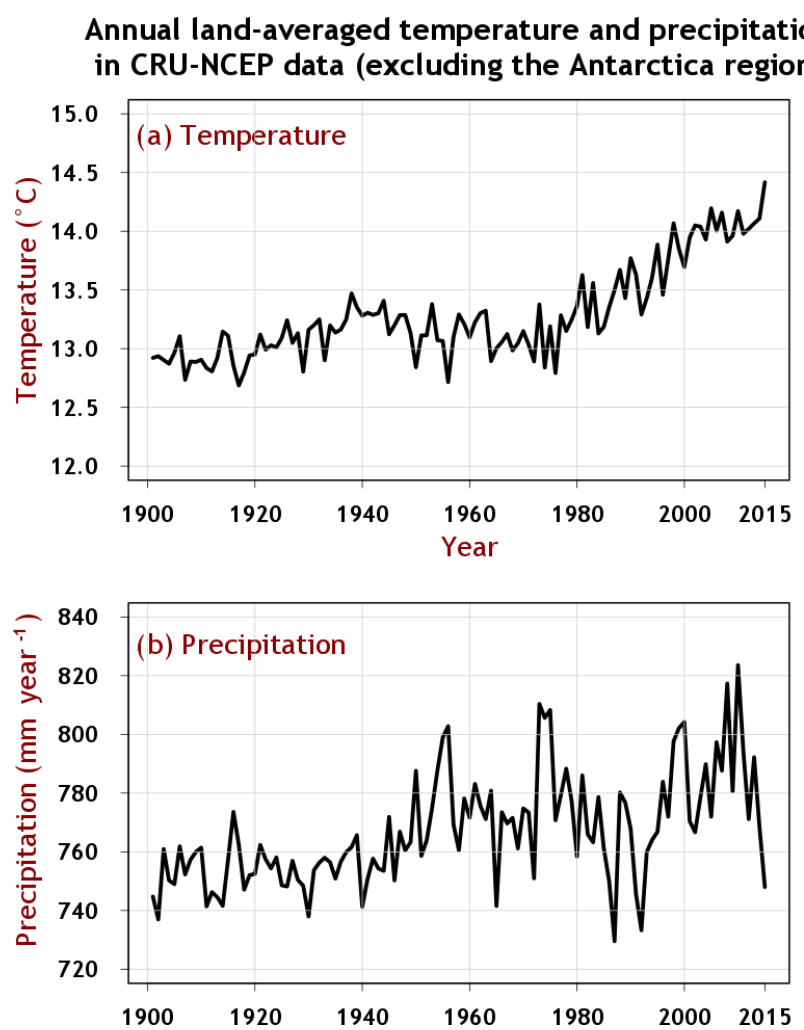

Figure B1. Annual land-averaged temperature and precipitation in version 7 of the CRU-NCEP data for the period 1901-2015, excluding the Antarctica region, that are used to drive the CLASS-CTEM model.

Globally-averaged $\mathrm{CO}_{2}$ and $\mathrm{CH}_{4}$ concentrations used to drive the CLASS-CTEM model
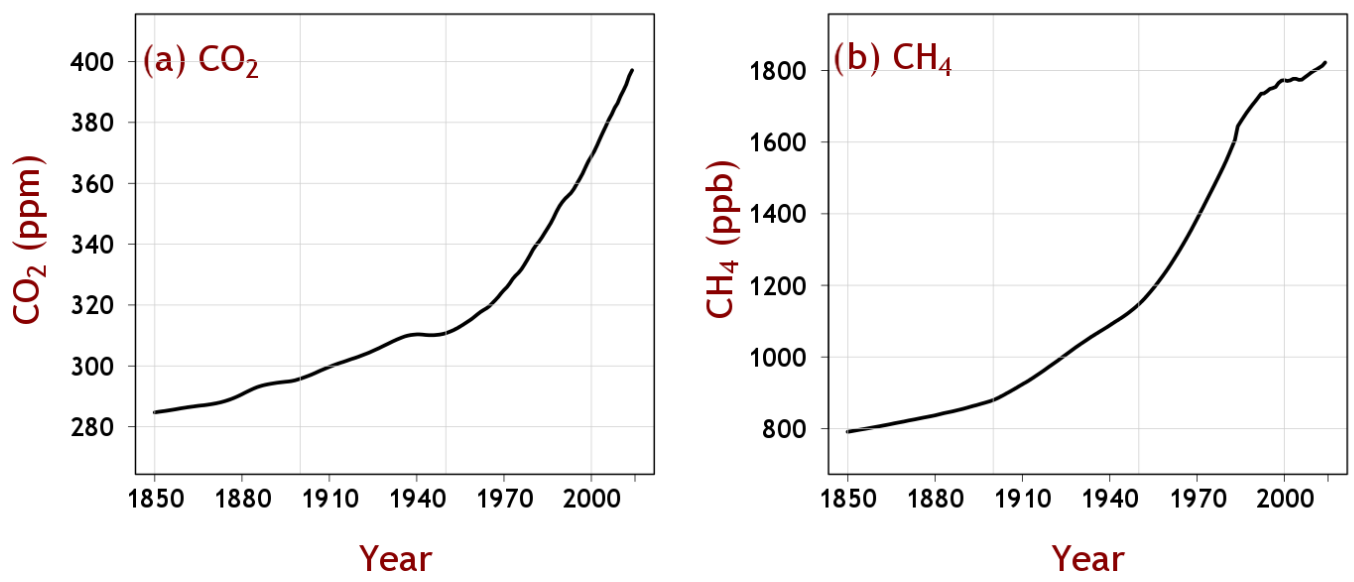

Figure B2. Globally averaged $\mathrm{CO}_{2}$ and $\mathrm{CH}_{4}$ concentrations used to drive the CLASS-CTEM model. 
Appendix C: Selected model results used to interpret methane emissions from wetland and fire

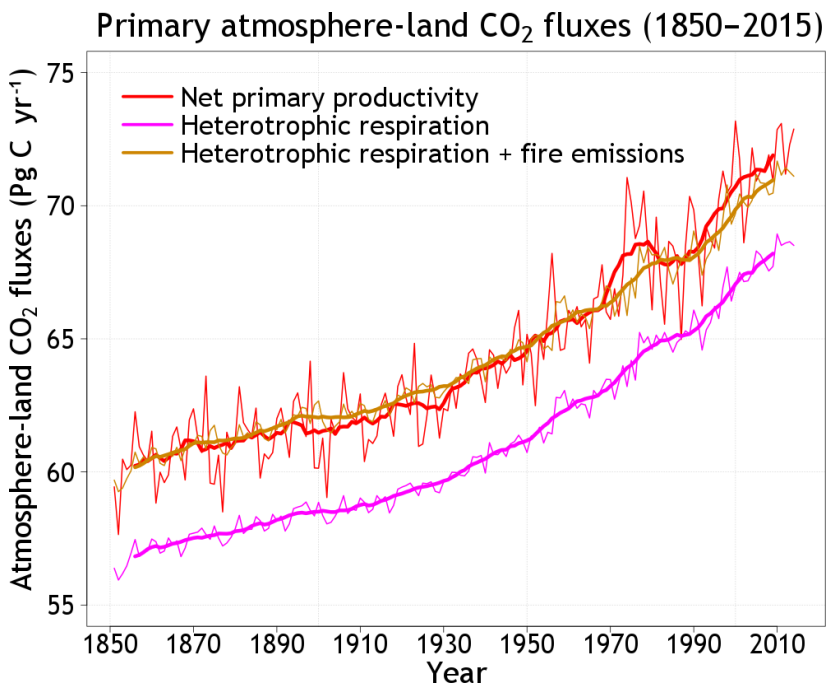

Figure C1. Time evolution of simulated net primary productivity (NPP) and heterotrophic respiration in the historical simulation both of which increase in response to increase in atmospheric $\mathrm{CO}_{2}$ concentration. The thin lines show annual values while the thick lines represent their 10-year moving average. When fire $\mathrm{CO}_{2}$ emissions are added to heterotrophic respiration the total amount is equal to NPP especially during the 1850 s as the case should be when the system is in equilibrium and net atmosphere-land $\mathrm{CO}_{2}$ flux (equal to NPP - heterotrophic respiration - fire emissions) is near zero. Later in the 20th century and early 21 st century, NPP is greater than the sum of heterotrophic respiration and fire $\mathrm{CO}_{2}$ emissions, which creates the sink over land that is currently observed.

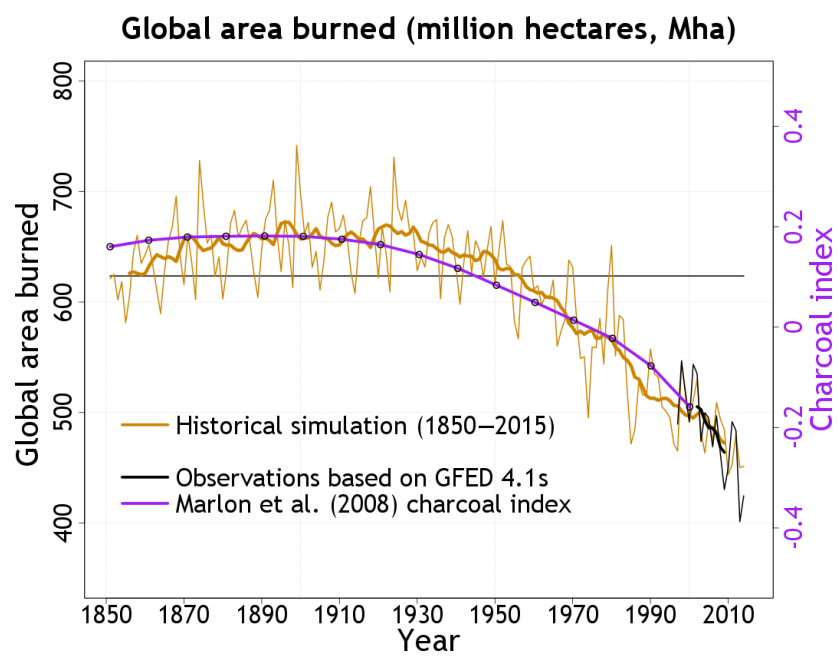

Figure C2. Comparison of global area burned from the transient 1851-2015 historical simulation (dark yellow line). The thick dark yellow line is the 10-year moving average. Observation-based area burned (black line) are based on the GFED 4.1s data set. Model results are also compared to decadal charcoal index from version 3 of the Global Charcoal Database (purple line). Charcoal index is a proxy for burning and not for area burned per se and thus only provides a qualitative measure. 
Author contributions. VKA wrote the majority of the manuscript and performed the CLASS-CTEM simulations. JRM developed the framework for running the global CLASS-CTEM simulations, did a literature review of wetlands and their methane emissions, and wrote parts of the manuscript. DP provided results from the CMAM model and wrote the text describing the results from the CMAM model and the related experimental protocol.

Competing interests. The authors declare that they have no conflict of interest.

Acknowledgements. We would like to thank Douglas Chan and Reinel Sospedra-Alfonso for providing comments on an earlier version of this manuscript. We also thank the two anonymous reviewers for their comments and our handling editor Alexey V. Eliseev for his time and effort.

Edited by: Alexey V. Eliseev

Reviewed by: two anonymous referees

\section{References}

Amante, C. and Eakins, B. W.: ETOPO1 1 Arc-Minute Global Relief Model: Procedures, Data Sources and Analysis, NOAA Technical Memorandum NESDIS NGDC-24, 19 pp., https://doi.org/10.7289/V5C8276M, 2009.

Andreae, M. O. and Merlet, P.: Emission of trace gases and aerosols from biomass burning, Global Biogeochem. Cy., 15, 955-966, https://doi.org/10.1029/2000GB001382, 2001.

Arora, V. K.: Land surface modelling in general circulation models: a hydrological perspective, $\mathrm{PhD}$ thesis, University of Melbourne, Melbourne, Australia, 1997.

Arora, V. K. and Boer, G. J.: A Representation of Variable Root Distribution in Dynamic Vegetation Models, Earth Interact., 7, 1-19, https://doi.org/10.1175/10873562(2003)007<0001:AROVRD>2.0.CO;2, 2003.

Arora, V. K. and Boer, G. J.: A parameterization of leaf phenology for the terrestrial ecosystem component of climate models, Glob. Change Biol., 11, 39-59, https://doi.org/10.1111/j.13652486.2004.00890.x, 2005a.

Arora, V. K. and Boer, G. J.: Fire as an interactive component of dynamic vegetation models, J. Geophys. Res.-Biogeo., 110, G02008, https://doi.org/10.1029/2005JG000042, 2005b.

Arora, V. K. and Boer, G. J.: Uncertainties in the 20th century carbon budget associated with land use change, Glob. Change Biol., 16, 3327-3348, https://doi.org/10.1111/j.13652486.2010.02202.x, 2010.

Arora, V. K. and Melton, J. R.: Reduction in global area burned and wildfire emissions since 1930s enhances carbon uptake by land, Nat. Commun., 9, 1326, https://doi.org/10.1038/s41467018-03838-0, 2018.

Arora, V. K. and Scinocca, J. F.: Constraining the strength of the terrestrial CO2 fertilization effect in the Canadian Earth system model version 4.2 (CanESM4.2), Geosci. Model Dev., 9, 23572376, https://doi.org/10.5194/gmd-9-2357-2016, 2016.
Arora, V. K., Boer, G. J., Christian, J. R., Curry, C. L., Denman, K. L., Zahariev, K., Flato, G. M., Scinocca, J. F., Merryfield, W. J., and Lee, W. G.: The Effect of Terrestrial Photosynthesis Down Regulation on the Twentieth-Century Carbon Budget Simulated with the CCCma Earth System Model, J. Climate, 22, 6066-6088, https://doi.org/10.1175/2009JCLI3037.1, 2009.

Arora, V. K., Scinocca, J. F., Boer, G. J., Christian, J. R., Denman, K. L., Flato, G. M., Kharin, V. V., Lee, W. G., and Merryfield, W. J.: Carbon emission limits required to satisfy future representative concentration pathways of greenhouse gases, Geophys. Res. Lett., 38, L05805, https://doi.org/10.1029/2010GL046270, 2011.

Arora, V. K., Boer, G. J., Friedlingstein, P., Eby, M., Jones, C. D., Christian, J. R., Bonan, G., Bopp, L., Brovkin, V., Cadule, P., Hajima, T., Ilyina, T., Lindsay, K., Tjiputra, J. F., and $\mathrm{Wu}, \mathrm{T}$.: Carbon-Concentration and Carbon-Climate Feedbacks in CMIP5 Earth System Models, J. Climate, 26, 5289-5314, https://doi.org/10.1175/JCLI-D-12-00494.1, 2013.

Arora, V. K., Peng, Y., Kurz, W. A., Fyfe, J. C., Hawkins, B., and Werner, A. T.: Potential near-future carbon uptake overcomes losses from a large insect outbreak in British Columbia, Canada, Geophys. Res. Lett., 43, 2590-2598, https://doi.org/10.1002/2015GL067532, 2016.

Bastviken, D., Cole, J., Pace, M., and Tranvik, L.: Methane emissions from lakes: Dependence of lake characteristics, two regional assessments, and a global estimate, Global Biogeochem. Cy., 18, GB4009, https://doi.org/10.1029/2004GB002238, 2004.

Bloom, A. A., Bowman, K. W., Lee, M., Turner, A. J., Schroeder, R., Worden, J. R., Weidner, R., McDonald, K. C., and Jacob, D. J.: A global wetland methane emissions and uncertainty dataset for atmospheric chemical transport models (WetCHARTs version 1.0), Geosci. Model Dev., 10, 2141-2156, https://doi.org/10.5194/gmd-10-2141-2017, 2017.

Bohn, T. J., Melton, J. R., Ito, A., Kleinen, T., Spahni, R., Stocker, B. D., Zhang, B., Zhu, X., Schroeder, R., Glagolev, M. V., Maksyutov, S., Brovkin, V., Chen, G., Denisov, S. N., Eliseev, A. V., Gallego-Sala, A., McDonald, K. C., Rawlins, M. A., Riley, W. J., Subin, Z. M., Tian, H., Zhuang, Q., and Kaplan, J. O.: WETCHIMP-WSL: intercomparison of wetland methane emissions models over West Siberia, Biogeosciences, 12, 3321-3349, https://doi.org/10.5194/bg-12-3321-2015, 2015.

Bousquet, P., Ringeval, B., Pison, I., Dlugokencky, E. J., Brunke, E.G., Carouge, C., Chevallier, F., Fortems-Cheiney, A., Frankenberg, C., Hauglustaine, D. A., Krummel, P. B., Langenfelds, R. L., Ramonet, M., Schmidt, M., Steele, L. P., Szopa, S., Yver, C., Viovy, N., and Ciais, P.: Source attribution of the changes in atmospheric methane for 2006-2008, Atmos. Chem. Phys., 11, 3689-3700, https://doi.org/10.5194/acp-11-3689-2011, 2011.

Chengjin, C., Megan, B., Youshi, W., Fangliang, H., Jacob, W., Jérôme, C., and Lawren, S.: Does climate directly influence NPP globally?, Glob. Change Biol., 22, 12-24, https://doi.org/10.1111/gcb.13079, 2016.

Collins, W. J., Bellouin, N., Doutriaux-Boucher, M., Gedney, N., Halloran, P., Hinton, T., Hughes, J., Jones, C. D., Joshi, M., Liddicoat, S., Martin, G., O’Connor, F., Rae, J., Senior, C., Sitch, S., Totterdell, I., Wiltshire, A., and Woodward, S.: Development and evaluation of an Earth-System model - HadGEM2, Geosci. Model Dev., 4, 1051-1075, https://doi.org/10.5194/gmd-4-10512011, 2011. 
Curry, C. L.: Modeling the soil consumption of atmospheric methane at the global scale, Global Biogeochem. Cy., 21, GB4012, https://doi.org/10.1029/2006GB002818, 2007.

Dalva, M., Moore, T. R., Arp, P., and Clair, T. A.: Methane and soil and plant community respiration from wetlands, Kejimkujik National Park, Nova Scotia: Measurements, predictions, and climatic change, J. Geophys. Res.-Atmos., 106, 2955-2962, https://doi.org/10.1029/2000JD900500, 2001.

Denman, K. L., Brasseur, G., Chidthaisong, A., Ciais, P., Cox, P. M., Dickinson, R. E., Hauglustaine, D., Heinze, C., Holland, E., Jacob, D., Lohmann, U., Ramachandran, S., da Silva Dias, P. L., Wofsy, S. C., and Zhang, H.: Couplings Between Changes in the Climate System and Biogeochemistry, in Climate Change 2007: The Physical Science Basis, Contribution of Working Group I to the Fourth Assessment Report of the Intergovernmental Panel on Climate Change, edited by: Solomon, S., Qin, D., Manning, M., Chen, Z., Marquis, M., Averyt, K. B., Tignor, M., and Miller, H. L., Cambridge University Press, Cambridge, UK and New York, NY, USA, 499-587, 2007.

European Commission: Wise use and conservation of wetlands. Communication from the Commission to the Council and the European Parliament, European Commission, Brussels, Belgium, available at: http://aei.pitt.edu/4792/1/4792.pdf (last access: 12 September 2017), 1995.

Eyring, V., Butchart, N., Waugh, D. W., Akiyoshi, H., Austin, J., Bekki, S., Bodeker, G. E., Boville, B. A., Brühl, C., Chipperfield, M. P., Cordero, E., Dameris, M., Deushi, M., Fioletov, V. E., Frith, S. M., Garcia, R. R., Gettelman, A., Giorgetta, M. A., Grewe, V., Jourdain, L., Kinnison, D. E., Mancini, E., Manzini, E., Marchand, M., Marsh, D. R., Nagashima, T., Newman, P. A., Nielsen, J. E., Pawson, S., Pitari, G., Plummer, D. A., Rozanov, E., Schraner, M., Shepherd, T. G., Shibata, K., Stolarski, R. S., Struthers, H., Tian, W., and Yoshiki, M.: Assessment of temperature, trace species, and ozone in chemistry-climate model simulations of the recent past, J. Geophys. Res.-Atmos., 111, D22308, https://doi.org/10.1029/2006JD007327, 2006.

Friedlingstein, P., Cox, P., Betts, R., Bopp, L., von Bloh, W., Brovkin, V., Cadule, P., Doney, S., Eby, M., Fung, I., Bala, G., John, J., Jones, C., Joos, F., Kato, T., Kawamiya, M., Knorr, W., Lindsay, K., Matthews, H. D., Raddatz, T., Rayner, P., Reick, C., Roeckner, E., Schnitzler, K.-G., Schnur, R., Strassmann, K., Weaver, A. J., Yoshikawa, C., and Zeng, N.: Climate-Carbon Cycle Feedback Analysis: Results from the C4MIP Model Intercomparison, J. Climate, 19, 3337-3353, https://doi.org/10.1175/JCLI3800.1, 2006.

Friedlingstein, P., Meinshausen, M., Arora, V. K., Jones, C. D., Anav, A., Liddicoat, S. K., and Knutti, R.: Uncertainties in CMIP5 Climate Projections due to Carbon Cycle Feedbacks, J. Climate, 27, 511-526, https://doi.org/10.1175/JCLI-D-12$00579.1,2014$.

Garnaud, C., Sushama, L., and Verseghy, D.: Impact of interactive vegetation phenology on the Canadian RCM simulated climate over North America, Clim. Dynam., 45, 1471-1492, https://doi.org/10.1007/s00382-014-2397-9, 2015.

Giglio, L., Randerson, J. T., and van der Werf, G. R.: Analysis of daily, monthly, and annual burned area using the fourthgeneration global fire emissions database (GFED4), J. Geophys. Res.-Biogeo., 118, 317-328, https://doi.org/10.1002/jgrg.20042, 2013.
GitLab: model code, available at: https://gitlab.com/jormelton/ classctem, last access: 25 July 2018.

Glagolev, M. V., Kleptsova, I. E., Filippov, I. V., Kazantsev, V. S., Machida, T., and Maksyutov, S. S.: Methane emissions from subtaiga mires of Western Siberia: The "standard model” Bc5, Mosc. Univ. Soil Sci. Bull., 65, 86-93, https://doi.org/10.3103/S0147687410020067, 2010.

Godwin, C. M., McNamara, P. J., and Markfort, C. D.: Evening methane emission pulses from a boreal wetland correspond to convective mixing in hollows, J. Geophys. Res.-Biogeo., 118, 994-1005, https://doi.org/10.1002/jgrg.20082, 2013.

Griffin, D. M.: Water potential as a selective factor in the microbial ecology of soils, in: Water Potential Relations in Soil Microbiology, edited by: Parr, J., Gardner, W., and Elliott, L., Soil Sci. Soc. Am. J., 141-151, 1981.

Houweling, S., Bergamaschi, P., Chevallier, F., Heimann, M., Kaminski, T., Krol, M., Michalak, A. M., and Patra, P.: Global inverse modeling of $\mathrm{CH}_{4}$ sources and sinks: an overview of methods, Atmos. Chem. Phys., 17, 235-256, https://doi.org/10.5194/acp-17-235-2017, 2017.

Hurtt, G. C., Frolking, S., Fearon, M. G., Moore, B., Shevliakova, E., Malyshev, S., Pacala, S. W., and Houghton, R. A.: The underpinnings of land-use history: three centuries of global gridded land-use transitions, wood-harvest activity, and resulting secondary lands, Glob. Change Biol., 12, 1208-1229, https://doi.org/10.1111/j.1365-2486.2006.01150.x, 2006.

Jones, C., Robertson, E., Arora, V., Friedlingstein, P., Shevliakova, E., Bopp, L., Brovkin, V., Hajima, T., Kato, E., Kawamiya, M., Liddicoat, S., Lindsay, K., Reick, C. H., Roelandt, C., Segschneider, J., and Tjiputra, J.: Twenty-First-Century Compatible $\mathrm{CO}_{2}$ Emissions and Airborne Fraction Simulated by CMIP5 Earth System Models under Four Representative Concentration Pathways, J. Climate, 26, 4398-4413, https://doi.org/10.1175/JCLID-12-00554.1, 2013.

Kaplan, J. O.: Wetlands at the Last Glacial Maximum: Distribution and methane emissions, Geophys. Res. Lett., 29, 1079, https://doi.org/10.1029/2001GL013366, 2002.

Kim, H.-S., Maksyutov, S., Glagolev, M. V., Machida, T., Patra, P. K., Sudo, K., and Inoue, G.: Evaluation of methane emissions from West Siberian wetlands based on inverse modeling, Environ. Res. Lett., 6, 035201, https://doi.org/10.1088/17489326/6/3/035201, 2011.

Kloster, S., Mahowald, N. M., Randerson, J. T., Thornton, P. E., Hoffman, F. M., Levis, S., Lawrence, P. J., Feddema, J. J., Oleson, K. W., and Lawrence, D. M.: Fire dynamics during the 20th century simulated by the Community Land Model, Biogeosciences, 7, 1877-1902, https://doi.org/10.5194/bg-7-18772010, 2010.

Lamarque, J.-F., Bond, T. C., Eyring, V., Granier, C., Heil, A., Klimont, Z., Lee, D., Liousse, C., Mieville, A., Owen, B., Schultz, M. G., Shindell, D., Smith, S. J., Stehfest, E., Van Aardenne, J., Cooper, O. R., Kainuma, M., Mahowald, N., McConnell, J. R., Naik, V., Riahi, K., and van Vuuren, D. P.: Historical (1850-2000) gridded anthropogenic and biomass burning emissions of reactive gases and aerosols: methodology and application, Atmos. Chem. Phys., 10, 7017-7039, https://doi.org/10.5194/acp-10-7017-2010, 2010.

Lamarque, J.-F., Shindell, D. T., Josse, B., Young, P. J., Cionni, I., Eyring, V., Bergmann, D., Cameron-Smith, P., Collins, W. J., Do- 
herty, R., Dalsoren, S., Faluvegi, G., Folberth, G., Ghan, S. J., Horowitz, L. W., Lee, Y. H., MacKenzie, I. A., Nagashima, T., Naik, V., Plummer, D., Righi, M., Rumbold, S. T., Schulz, M., Skeie, R. B., Stevenson, D. S., Strode, S., Sudo, K., Szopa, S., Voulgarakis, A., and Zeng, G.: The Atmospheric Chemistry and Climate Model Intercomparison Project (ACCMIP): overview and description of models, simulations and climate diagnostics, Geosci. Model Dev., 6, 179-206, https://doi.org/10.5194/gmd-6179-2013, 2013.

Langer, M., Westermann, S., Walter Anthony, K., Wischnewski, K., and Boike, J.: Frozen ponds: production and storage of methane during the Arctic winter in a lowland tundra landscape in northern Siberia, Lena River delta, Biogeosciences, 12, 977-990, https://doi.org/10.5194/bg-12-977-2015, 2015.

Lehner, B. and Döll, P.: Development and validation of a global database of lakes, reservoirs and wetlands, J. Hydrol., 296, 1-22, https://doi.org/10.1016/j.jhydrol.2004.03.028, 2004.

Le Quéré, C., Andrew, R. M., Friedlingstein, P., Sitch, S., Pongratz, J., Manning, A. C., Korsbakken, J. I., Peters, G. P., Canadell, J. G., Jackson, R. B., Boden, T. A., Tans, P. P., Andrews, O. D., Arora, V. K., Bakker, D. C. E., Barbero, L., Becker, M., Betts, R. A., Bopp, L., Chevallier, F., Chini, L. P., Ciais, P., Cosca, C. E., Cross, J., Currie, K., Gasser, T., Harris, I., Hauck, J., Haverd, V., Houghton, R. A., Hunt, C. W., Hurtt, G., Ilyina, T., Jain, A. K., Kato, E., Kautz, M., Keeling, R. F., Klein Goldewijk, K., Körtzinger, A., Landschützer, P., Lefèvre, N., Lenton, A., Lienert, S., Lima, I., Lombardozzi, D., Metzl, N., Millero, F., Monteiro, P. M. S., Munro, D. R., Nabel, J. E. M. S., Nakaoka, S.-I., Nojiri, Y., Padin, X. A., Peregon, A., Pfeil, B., Pierrot, D., Poulter, B., Rehder, G., Reimer, J., Rödenbeck, C., Schwinger, J., Séférian, R., Skjelvan, I., Stocker, B. D., Tian, H., Tilbrook, B., Tubiello, F. N., van der Laan-Luijkx, I. T., van der Werf, G. R., van Heuven, S., Viovy, N., Vuichard, N., Walker, A. P., Watson, A. J., Wiltshire, A. J., Zaehle, S., and Zhu, D.: Global Carbon Budget 2017, Earth Syst. Sci. Data, 10, 405-448, https://doi.org/10.5194/essd-10-405-2018, 2018.

Li, F., Zeng, X. D., and Levis, S.: A process-based fire parameterization of intermediate complexity in a Dynamic Global Vegetation Model, Biogeosciences, 9, 2761-2780, https://doi.org/10.5194/bg-9-2761-2012, 2012.

Marlon, J. R., Bartlein, P. J., Carcaillet, C., Gavin, D. G., Harrison, S. P., Higuera, P. E., Joos, F., Power, M. J., and Prentice, I. C.: Climate and human influences on global biomass burning over the past two millennia, Nat. Geosci, 1, 697-702, https://doi.org/10.1038/ngeo313, 2008.

Matthes, K., Funke, B., Andersson, M. E., Barnard, L., Beer, J., Charbonneau, P., Clilverd, M. A., Dudok de Wit, T., Haberreiter, M., Hendry, A., Jackman, C. H., Kretzschmar, M., Kruschke, T., Kunze, M., Langematz, U., Marsh, D. R., Maycock, A. C., Misios, S., Rodger, C. J., Scaife, A. A., Seppälä, A., Shangguan, M., Sinnhuber, M., Tourpali, K., Usoskin, I., van de Kamp, M., Verronen, P. T., and Versick, S.: Solar forcing for CMIP6 (v3.2), Geosci. Model Dev., 10, 2247-2302, https://doi.org/10.5194/gmd-10-2247-2017, 2017.

Matthews, E. and Fung, I.: Methane emission from natural wetlands: Global distribution, area, and environmental characteristics of sources, Global Biogeochem. Cy., 1, 61-86, https://doi.org/10.1029/GB001i001p00061, 1987.
Meinshausen, M., Smith, S. J., Calvin, K., Daniel, J. S., Kainuma, M. L. T., Lamarque, J.-F., Matsumoto, K., Montzka, S. A., Raper, S. C. B., Riahi, K., Thomson, A., Velders, G. J. M., and van Vuuren, D. P. P.: The RCP greenhouse gas concentrations and their extensions from 1765 to 2300, Clim. Change, 109, 213, https://doi.org/10.1007/s10584-011-0156-z, 2011.

Melton, J. R. and Arora, V. K.: Sub-grid scale representation of vegetation in global land surface schemes: implications for estimation of the terrestrial carbon sink, Biogeosciences, 11, 10211036, https://doi.org/10.5194/bg-11-1021-2014, 2014.

Melton, J. R. and Arora, V. K.: Competition between plant functional types in the Canadian Terrestrial Ecosystem Model (CTEM) v. 2.0, Geosci. Model Dev., 9, 323-361, https://doi.org/10.5194/gmd-9-323-2016, 2016.

Melton, J. R., Wania, R., Hodson, E. L., Poulter, B., Ringeval, B., Spahni, R., Bohn, T., Avis, C. A., Beerling, D. J., Chen, G., Eliseev, A. V., Denisov, S. N., Hopcroft, P. O., Lettenmaier, D. P., Riley, W. J., Singarayer, J. S., Subin, Z. M., Tian, H., Zürcher, S., Brovkin, V., van Bodegom, P. M., Kleinen, T., Yu, Z. C., and Kaplan, J. O.: Present state of global wetland extent and wetland methane modelling: conclusions from a model intercomparison project (WETCHIMP), Biogeosciences, 10, 753788, https://doi.org/10.5194/bg-10-753-2013, 2013.

Melton, J. R., Shrestha, R. K., and Arora, V. K.: The influence of soils on heterotrophic respiration exerts a strong control on net ecosystem productivity in seasonally dry Amazonian forests, Biogeosciences, 12, 1151-1168, https://doi.org/10.5194/bg-121151-2015, 2015.

Migliavacca, M., Dosio, A., Kloster, S., Ward, D. S., Camia, A., Houborg, R., Houston Durrant, T., Khabarov, N., Krasovskii, A. A., San Miguel-Ayanz, J., and Cescatti, A.: Modeling burned area in Europe with the Community Land Model, J. Geophys. Res.-Biogeo., 118, 265-279, https://doi.org/10.1002/jgrg.20026, 2013.

Myhre, G., Shindell, D., Bréon, F.-M., Collins, W., Fuglestvedt, J., Huang, J., Koch, D., Lamarque, J.-F., Lee, D., Mendoza, B., Nakajima, T., Robock, A., Stephens, G., Takemura, T. and Zhang, H.: Anthropogenic and Natural Radiative Forcing, in: Climate Change 2013: The Physical Science Basis. Contribution of Working Group I to the Fifth Assessment Report of the Intergovernmental Panel on Climate Change, edited by: Stocker, T. F., Qin, D., Plattner, G.-K., Tignor, M., Allen, S. K., Boschung, J., Nauels, A., Xia, Y., Bex, V., and Midgley, P. M.: Cambridge University Press, Cambridge, UK and New York, NY, USA, 659 740, 2013.

Naik, V., Voulgarakis, A., Fiore, A. M., Horowitz, L. W., Lamarque, J.-F., Lin, M., Prather, M. J., Young, P. J., Bergmann, D., Cameron-Smith, P. J., Cionni, I., Collins, W. J., Dalsøren, S. B., Doherty, R., Eyring, V., Faluvegi, G., Folberth, G. A., Josse, B., Lee, Y. H., MacKenzie, I. A., Nagashima, T., van Noije, T. P. C., Plummer, D. A., Righi, M., Rumbold, S. T., Skeie, R., Shindell, D. T., Stevenson, D. S., Strode, S., Sudo, K., Szopa, S., and Zeng, G.: Preindustrial to present-day changes in tropospheric hydroxyl radical and methane lifetime from the Atmospheric Chemistry and Climate Model Intercomparison Project (ACCMIP), Atmos. Chem. Phys., 13, 5277-5298, https://doi.org/10.5194/acp13-5277-2013, 2013.

Neely III, R. R., Conley, A. J., Vitt, F., and Lamarque, J.-F.: A consistent prescription of stratospheric aerosol for both radiation 
and chemistry in the Community Earth System Model (CESM1), Geosci. Model Dev., 9, 2459-2470, https://doi.org/10.5194/gmd9-2459-2016, 2016.

Papa, F., Prigent, C., Aires, F., Jimenez, C., Rossow, W. B., and Matthews, E.: Interannual variability of surface water extent at the global scale, 1993-2004, J. Geophys. Res.-Atmos., 115, D12111, https://doi.org/10.1029/2009JD012674, 2010.

Peng, Y., Arora, V. K., Kurz, W. A., Hember, R. A., Hawkins, B. J., Fyfe, J. C., and Werner, A. T.: Climate and atmospheric drivers of historical terrestrial carbon uptake in the province of British Columbia, Canada, Biogeosciences, 11, 635-649, https://doi.org/10.5194/bg-11-635-2014, 2014.

Peregon, A., Maksyutov, S., and Yamagata, Y.: An image-based inventory of the spatial structure of West Siberian wetlands, Environ. Res. Lett., 4, 045014, https://doi.org/10.1088/17489326/4/4/045014, 2009.

Poulter, B., Bousquet, P., Canadell, J. G., Ciais, P., Peregon, A., Marielle Saunois, Arora, V. K., Beerling, D. J., Brovkin, V., Jones, C. D., Joos, F., Nicola Gedney, Ito, A., Kleinen, T., Koven, C. D., McDonald, K., Melton, J. R., Peng, C., Shushi Peng, Prigent, C., Schroeder, R., Riley, W. J., Saito, M., Spahni, R., Tian, H., Lyla Taylor, Viovy, N., Wilton, D., Wiltshire, A., Xu, X., Zhang, B., Zhang, Z., and Zhu, Q.: Global wetland contribution to 2000-2012 atmospheric methane growth rate dynamics, Environ. Res. Lett., 12, 094013, https://doi.org/10.1088/17489326/aa8391, 2017.

Prather, M. J., Holmes, C. D., and Hsu, J.: Reactive greenhouse gas scenarios: Systematic exploration of uncertainties and the role of atmospheric chemistry, Geophys. Res. Lett., 39, L09803, https://doi.org/10.1029/2012GL051440, 2012.

Prigent, C., Papa, F., Aires, F., Rossow, W. B., and Matthews, E.: Global inundation dynamics inferred from multiple satellite observations, 1993-2000, J. Geophys. Res.-Atmos., 112, D12107, https://doi.org/10.1029/2006JD007847, 2007.

Randerson, J. T., Chen, Y., van der Werf, G. R., Rogers, B. M., and Morton, D. C.: Global burned area and biomass burning emissions from small fires, J. Geophys. Res.-Biogeo., 117, G04012, https://doi.org/10.1029/2012JG002128, 2012.

Saunois, M., Bousquet, P., Poulter, B., Peregon, A., Ciais, P., Canadell, J. G., Dlugokencky, E. J., Etiope, G., Bastviken, D., Houweling, S., Janssens-Maenhout, G., Tubiello, F. N., Castaldi, S., Jackson, R. B., Alexe, M., Arora, V. K., Beerling, D. J., Bergamaschi, P., Blake, D. R., Brailsford, G., Brovkin, V., Bruhwiler, L., Crevoisier, C., Crill, P., Covey, K., Curry, C., Frankenberg, C., Gedney, N., Höglund-Isaksson, L., Ishizawa, M., Ito, A., Joos, F., Kim, H.-S., Kleinen, T., Krummel, P., Lamarque, J.-F., Langenfelds, R., Locatelli, R., Machida, T., Maksyutov, S., McDonald, K. C., Marshall, J., Melton, J. R., Morino, I., Naik, V., O'Doherty, S., Parmentier, F.-J. W., Patra, P. K., Peng, C., Peng, S., Peters, G. P., Pison, I., Prigent, C., Prinn, R., Ramonet, M., Riley, W. J., Saito, M., Santini, M., Schroeder, R., Simpson, I. J., Spahni, R., Steele, P., Takizawa, A., Thornton, B. F., Tian, H., Tohjima, Y., Viovy, N., Voulgarakis, A., van Weele, M., van der Werf, G. R., Weiss, R., Wiedinmyer, C., Wilton, D. J., Wiltshire, A., Worthy, D., Wunch, D., Xu, X., Yoshida, Y., Zhang, B., Zhang, Z., and Zhu, Q.: The global methane budget 2000-2012, Earth Syst. Sci. Data, 8, 697-751, https://doi.org/10.5194/essd-8-697-2016, 2016.
Schroeder, R., McDonald, C. K., Chapman, D. B., Jensen, K., Podest, E., Tessler, D. Z., Bohn, J. T., and Zimmermann, R.: Development and Evaluation of a Multi-Year Fractional Surface Water Data Set Derived from Active/Passive Microwave Remote Sensing Data, Remote Sens., 7, 16688-16732, https://doi.org/10.3390/rs71215843, 2015.

Scinocca, J. F., McFarlane, N. A., Lazare, M., Li, J., and Plummer, D.: Technical Note: The CCCma third generation AGCM and its extension into the middle atmosphere, Atmos. Chem. Phys., 8, 7055-7074, https://doi.org/10.5194/acp-8-7055-2008, 2008.

Shindell, D., Kuylenstierna, J. C. I., Vignati, E., van Dingenen, R., Amann, M., Klimont, Z., Anenberg, S. C., Muller, N., JanssensMaenhout, G., Raes, F., Schwartz, J., Faluvegi, G., Pozzoli, L., Kupiainen, K., Höglund-Isaksson, L., Emberson, L., Streets, D., Ramanathan, V., Hicks, K., Oanh, N. T. K., Milly, G., Williams, M., Demkine, V., and Fowler, D.: Simultaneously Mitigating Near-Term Climate Change and Improving Human Health and Food Security, Science, 335, 183-189, 2012.

Shindell, D. T., Pechony, O., Voulgarakis, A., Faluvegi, G., Nazarenko, L., Lamarque, J.-F., Bowman, K., Milly, G., Kovari, B., Ruedy, R., and Schmidt, G. A.: Interactive ozone and methane chemistry in GISS-E2 historical and future climate simulations, Atmos. Chem. Phys., 13, 2653-2689, https://doi.org/10.5194/acp-13-2653-2013, 2013.

SPARC CCMVal: SPARC Report on the Evaluation of ChemistryClimate Models, edited by: Eyring, V., Shepherd, T. G., and Waugh, D. W., SPARC Report No. 5, WCRP-132, WMO/TDNo. 1526, 2010.

Thornton Brett, F., Wik, M., and Carill Patrick, M.: Doublecounting challenges the accuracy of high-latitude methane inventories, Geophys. Res. Lett., 43, 12569-12577, https://doi.org/10.1002/2016GL071772, 2016.

Verseghy, D. L.: Class - A Canadian land surface scheme for GCMS. I. Soil model, Int. J. Climatol., 11, 111-133, https://doi.org/10.1002/joc.3370110202, 1991.

Verseghy, D. L.: The Canadian land surface scheme (CLASS): Its history and future, Atmos.-Ocean, 38, 1-13, https://doi.org/10.1080/07055900.2000.9649637, 2000.

Verseghy, D. L., McFarlane, N. A., and Lazare, M.: Class - A Canadian land surface scheme for GCMS, II. Vegetation model and coupled runs, Int. J. Climatol., 13, 347-370, https://doi.org/10.1002/joc.3370130402, 1993.

Voulgarakis, A., Naik, V., Lamarque, J.-F., Shindell, D. T., Young, P. J., Prather, M. J., Wild, O., Field, R. D., Bergmann, D., CameronSmith, P., Cionni, I., Collins, W. J., Dalsøren, S. B., Doherty, R. M., Eyring, V., Faluvegi, G., Folberth, G. A., Horowitz, L. W., Josse, B., MacKenzie, I. A., Nagashima, T., Plummer, D. A., Righi, M., Rumbold, S. T., Stevenson, D. S., Strode, S. A., Sudo, K., Szopa, S., and Zeng, G.: Analysis of present day and future $\mathrm{OH}$ and methane lifetime in the ACCMIP simulations, Atmos. Chem. Phys., 13, 2563-2587, https://doi.org/10.5194/acp13-2563-2013, 2013.

Walter, B. P. and Heimann, M.: A process-based, climate-sensitive model to derive methane emissions from natural wetlands: Application to five wetland sites, sensitivity to model parameters, and climate, Global. Biogeochem. Cy., 14, 745-765, https://doi.org/10.1029/1999GB001204, 2000.

Wania, R., Ross, I., and Prentice, I. C.: Implementation and evaluation of a new methane model within a dynamic global vegetation 
model: LPJ-WHyMe v1.3.1, Geosci. Model Dev., 3, 565-584, https://doi.org/10.5194/gmd-3-565-2010, 2010.

Winderlich, J.: Setup of a $\mathrm{CO}_{2}$ and $\mathrm{CH}_{4}$ measurement system in Central Siberia and modeling of its results, Max-Planck-Institut für Biogeochemie, Jena, Germany, available at: http://ediss.sub. uni-hamburg.de/volltexte/2012/5533/pdf/Dissertation.pdf (last access: May 2018), 2012.

Young, P. J., Archibald, A. T., Bowman, K. W., Lamarque, J.-F., Naik, V., Stevenson, D. S., Tilmes, S., Voulgarakis, A., Wild, O., Bergmann, D., Cameron-Smith, P., Cionni, I., Collins, W. J., Dalsøren, S. B., Doherty, R. M., Eyring, V., Faluvegi, G., Horowitz, L. W., Josse, B., Lee, Y. H., MacKenzie, I. A., Nagashima, T., Plummer, D. A., Righi, M., Rumbold, S. T., Skeie, R. B., Shindell, D. T., Strode, S. A., Sudo, K., Szopa, S., and Zeng, G.: Preindustrial to end 21 st century projections of tropospheric ozone from the Atmospheric Chemistry and Climate Model Intercomparison Project (ACCMIP), Atmos. Chem. Phys., 13, 20632090, https://doi.org/10.5194/acp-13-2063-2013, 2013.
Zhu, Q., Liu, J., Peng, C., Chen, H., Fang, X., Jiang, H., Yang, G., Zhu, D., Wang, W., and Zhou, X.: Modelling methane emissions from natural wetlands by development and application of the TRIPLEX-GHG model, Geosci. Model Dev., 7, 981-999, https://doi.org/10.5194/gmd-7-981-2014, 2014.

Zhu, X., Zhuang, Q., Lu, X., and Song, L.: Spatial scale-dependent land-atmospheric methane exchanges in the northern high latitudes from 1993 to 2004, Biogeosciences, 11, 1693-1704, https://doi.org/10.5194/bg-11-1693-2014, 2014.

Zobler, L.: A World Soil File for Global Climate Modelling, NASA Technical Memorandum 87802, NASA Goddard Institute for Space Studies, New York, USA, 1986.

Zona, D., Gioli, B., Commane, R., Lindaas, J., Wofsy, S. C., Miller, C. E., Dinardo, S. J., Dengel, S., Sweeney, C., Karion, A., Chang, R. Y.-W., Henderson, J. M., Murphy, P. C., Goodrich, J. P., Moreaux, V., Liljedahl, A., Watts, J. D., Kimball, J. S., Lipson, D. A., and Oechel, W. C.: Cold season emissions dominate the Arctic tundra methane budget, P. Natl. Acad. Sci. USA, 113, 40-45, 2016. 